\title{
Design/Installation and Structural Integrity Assessment Under the Federal Facility Agreement for Bethel Valley Low-Level Waste Collection and Transfer System Upgrade for Building 2026 (High Radiation Level Analytical Laboratory) and Building 2099 (Monitoring and Control Station) at Oak Ridge National Laboratory
}

\author{
DISCLAIMER
}

\begin{abstract}
This report was prepared as an account of work sponsored by an agency of the United States Government. Neither the United States Government nor any agency thereof, nor any of their employees, makes any warranty, express or implied, or assumes any legal liability or responsibility for the accuracy, completeness, or usefulness of any information, apparatus, product, or process disclosed, or represents that its use would not infringe privately owned rights. Reference herein to any specific commercial product, process, or service by trade name, trademark, manufacturer, or otherwise does not necessarily constitute or imply its endorsement, recommendation, or favoring by the United States Government or any agency thereof. The views and opinions of authors expressed herein do not necessarily state or reflect those of the United States Government or any agency thereof.
\end{abstract}

Date Issued-November 1994

Prepared by

Gilbert/Commonwealth, Inc.

Prepared for

U.S. Department of Energy

Office of Environmental Restoration and Waste Management under budget and reporting code EW 20

Environmental Restoration and Waste Management Programs

Oak Ridge National Laboratory

Oak Ridge, Tennessee 37831-6285

managed by

MARTIN MARIETTA ENERGY SYSTEMS, INC.

for the

U.S. DEPARTMENT OF ENERGY

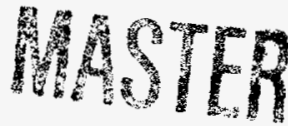

under contract DE-AC05-84OR21400

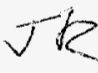




\section{DISCLAIMER}

Portions of this document may be illegible in electronic image products. Images are produced from the best available original document. 
Page

1. Introduction 1

II. Description of Project 2

III. Purpose of Project 4

IV. Assessment Results 6

A. Introduction 6

B. Standards for Design/Installation of New or Replacement Tank Systems

1. Design Installation Assessment 10

(a) Design Standards 10

(b) Hazardous Substance Characteristics 27

(c) Corrosion Protection 30

(d) Vehicular Traffic Protection 33

(e) Design Considerations 34

2. Tank Systems Installation 37

3. Inspection Reports 44

4. Backfilling 46

5. Testing 49

6. Ancillary Equipment Protection 49

7. Corrosion Protection 51

8. Corrosion Expert 52

9. Documentation 52 


\section{TABLE OF CONTENTS}

Page

C. Standards for Containment/Release Detection 55

1. Secondary Containment Systems Requirements 55

(a) Construction Compatibility 55

(b) Containment Systems Foundation 57

(c) Leak Detection System 58

(d) Drainage and Liquid Removal 60

(e) Secondary Containment for Tanks 62

(f) Additional Requirements 62

$\begin{array}{ll}\text { V. Conclusions } & 73\end{array}$

Appendix. LISTINGS OF DRAWINGS AND DOCUMENTS 
This document presents a Design/Installation and Structural Integrity Assessment for a replacement tank system for portions of the Bethel Valley Low Level Waste (LLW) System, located at the Oak Ridge Reservation, Oak Ridge, Tennessee. This issue of the assessment covers the design aspects of the replacement tank system, and certifies that the design has sufficient structural integrity and is acceptable for the storing or treating of hazardous and/or radioactive substances.

This document will be reissued at a future date and will then include the assessment of the installation of the replacement tank system. The present issue identifies specific activities that must be completed during the fabrication, installation, and testing of the replacement tank system in order to provide assurance that the final installation complies with governing requirements. These requirements are based on meeting the intent of 40CFR264 Subpart J -Tank Systems, as set forth in Appendix $F$ to the Federal Facility Agreement, Docket No. 89-04-FF, covering the Oak Ridge Reservation.

The assessment presented in this document is responsive to the Environmental Restoration Agreement for the Oak Ridge Reservation. The format utilized in preparation of the document follows the format presented in Appendix F, Low Level Radioactive Waste Tank Systems, appended to the Agreement. 
The LLW system at Oak Ridge National Laboratory (ORNL) consists of facilities to collect, transfer, concentrate, and store aqueous radioactive waste solutions from various sources at the Laboratory. The system is designed to accommodate waste solutions having an activity content as high as $5 \mathrm{Ci} / \mathrm{gal}$. The collection and transfer system consists of an extensive network of underground piping, valve boxes, and collection tanks. It allows for collection of LLW from the various source facilities and periodic transfer through the Central Waste Collection Header ( $\mathrm{CWCH}$ ) to the storage tanks serving the Laboratory's central LLW evaporator. Status of various system operations is centrally monitored at the Laboratory's Waste Operations Control Center (WOCC). Wastes are concentrated at the evaporator, and the concentrate is collected in a local storage tank and periodically transferred to tanks located in the Melton Valley area of the Laboratory for ultimate storage.

The Exhibit II-1 presents a map of a portion of the Bethel Valley complex. showing all of the facilities, existing and new, that comprise the entire scope of the Bethel Valley LLW Upgrade Project. This assessment report pertains to the modifications to be made to the existing High Radiation Analytical Laboratory (Building 2026) to achieve compliance with the Federal Facility Agreement, including the provision of a new Monitoring and Control Station (Building 2099) to receive, store, and treat (adjust $\mathrm{pH}$ ) low level radioactive waste. This work is described in Sections III and IV of this report.

The limits of the probable maximum floods due to extreme flood stage for White Oak Creek, are superimposed on the map. As may be noted, site flooding from this type of phenomena is not a credible event for the Building 2026/2099 portion of the upgrade. 


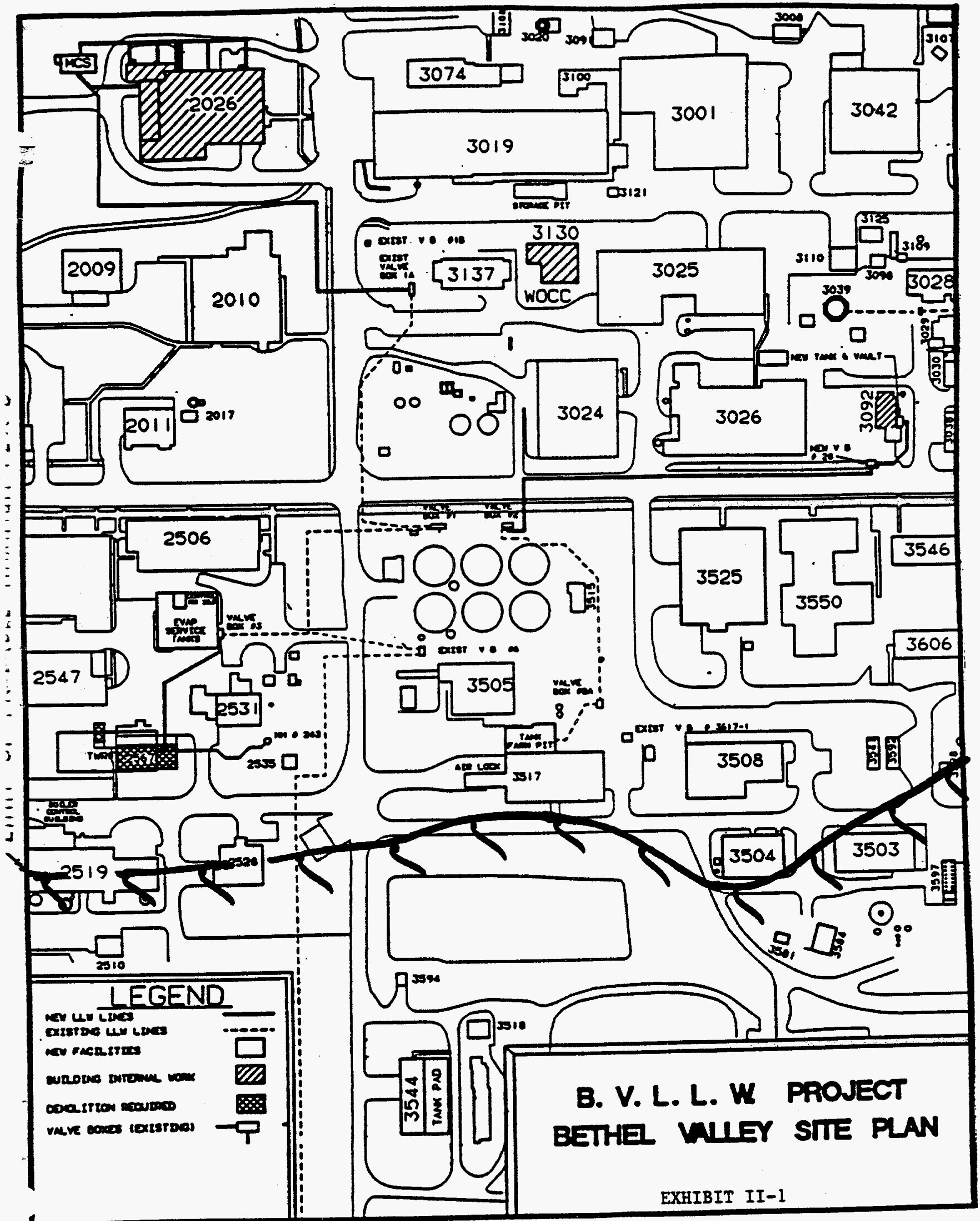




\section{PURPOSE OF PROJECT}

Portions of the LLW system are several decades old, or older, and do not comply with current environmental protection regulations. Several subsystems of the LLW system have been designated to receive a state-of-the-art replacement and refurbishment. One such subsystem serves Building 2026, the High Radiation Level Analytical Laboratory. This assessment focuses on the scope of work for the Building 2026 replacement LLW Collection and Transfer System, which is comprised of the following:

- Replacement of the existing collection piping within the Building 2026 facility.

- $\quad$ Addition of new buried double wall piping connecting Building 2026 with a new Monitoring and Control Station (MCS), Building 2099, and addition of new buried double wall piping connecting the MCS with a tie-in point to the Central Waste Collection Header at an existing valve box, No. 1 A.

- Addition of new MCS, Building 2099, comprised of a stainless steel LLW tank in a lined underground concrete vault, with leak detection, $\mathrm{pH}$ monitoring and adjustment capability, an HVAC system with extensive HEPA filtration, and a control room. The new LLW tank replaces an existing collection tank, designated F-401, located near the southeast corner of Building 2026, in a concrete vault founded approximately 20 feet below grade. The old tank is a single wall vessel, fabricated of Hastelloy- $C$ material, that has been in service for approximately 27 years and that does not comply with current environmental protection regulations.

- For the purpose of this assessment, the following terms are defined:

- Tank is defined as the LLW tank provided in the MCS tank vault; this term is limited to the tank proper and excludes the tank vault, liners, and other design features. 
- Tank System is defined as the entire fluid retaining system for LLW from the source building to the MCS and then to valve box No. $1 \mathrm{~A}$. This includes the LLW tank, the lined vault (with stainless steel inner liner), the sump in the vault with level detection instrumentation, the accumulated liquid removal subsystem (steam jet ejector and associated piping), piping connecting the source building (2026) with the MCS (2099) and connecting the MCS with valve box No. $1 \mathrm{~A}$.

- Primary Fluid Boundary is defined as piping containing the LLW, including single wall piping within buildings, the inner pipe in double wall pipe runs, and the LLW tank.

- Secondary Containment is defined as the outer pipe in double wall pipe runs and the reinforced concrete tank vaults, with inner stainless steel liner, at the MCS.

- Support Equipment is defined as, but not necessarily limited to, equipment required for system functional capability, such as sump level instrumentation, steam jet ejectors and associated piping and valves, and ventilating equipment for the tank and vaults. 


\section{ASSESSMENT RESULTS}

A. Introduction

This assessment covers the LLW Collection, and Transfer System designed for installation to serve Building 2026, High Radiation Level Analytical Laboratory; Building 2099, the MCS receiving waste from Building 2026; and piping systems connecting Building 2026 with Building 2099 and Building 2099 with the ORNL CWCH. The transfer line from Building 2099 terminates at, and connects to, the $\mathrm{CWCH}$ at existing valve box No. $1 \mathrm{~A}$.

This assessment reviews the design of the replacement Tank System for the above described Building 2026/2099 complex (Section IV.B). The assessment also covers the secondary containment provisions and ancillary equipment associated with the Building 2026/2099 complex (Section IV.C). Simplified diagrams illustrating the schematic and physical aspects of this LLW subsystem are shown in Exhibits IV-I and IV-2.

Several design conditions are presented for evaluation, as follows:

- Single wall pipe routed within a building, where the pipe is visible for routine (i.e., daily) visual inspection to detect leakage. Potential leakage is limited to small amounts of fluid that would be detected by routine observations and could not be directly released to the environment since it would spill or drip on floors, walls, or interior building furnishings. This condition is manifested in portions of the new Building 2026 internal piping, which consists of small diameter drain lines serving laboratory hoods and sinks.

- Single wall pipe routed within a vaulted structure, where the piping is not visible for routine visual inspection. Potential leakage would be contained and detected by the retention and leak detection capabilities of the stainless steel lined vault (described in IV.C of this assessment). 


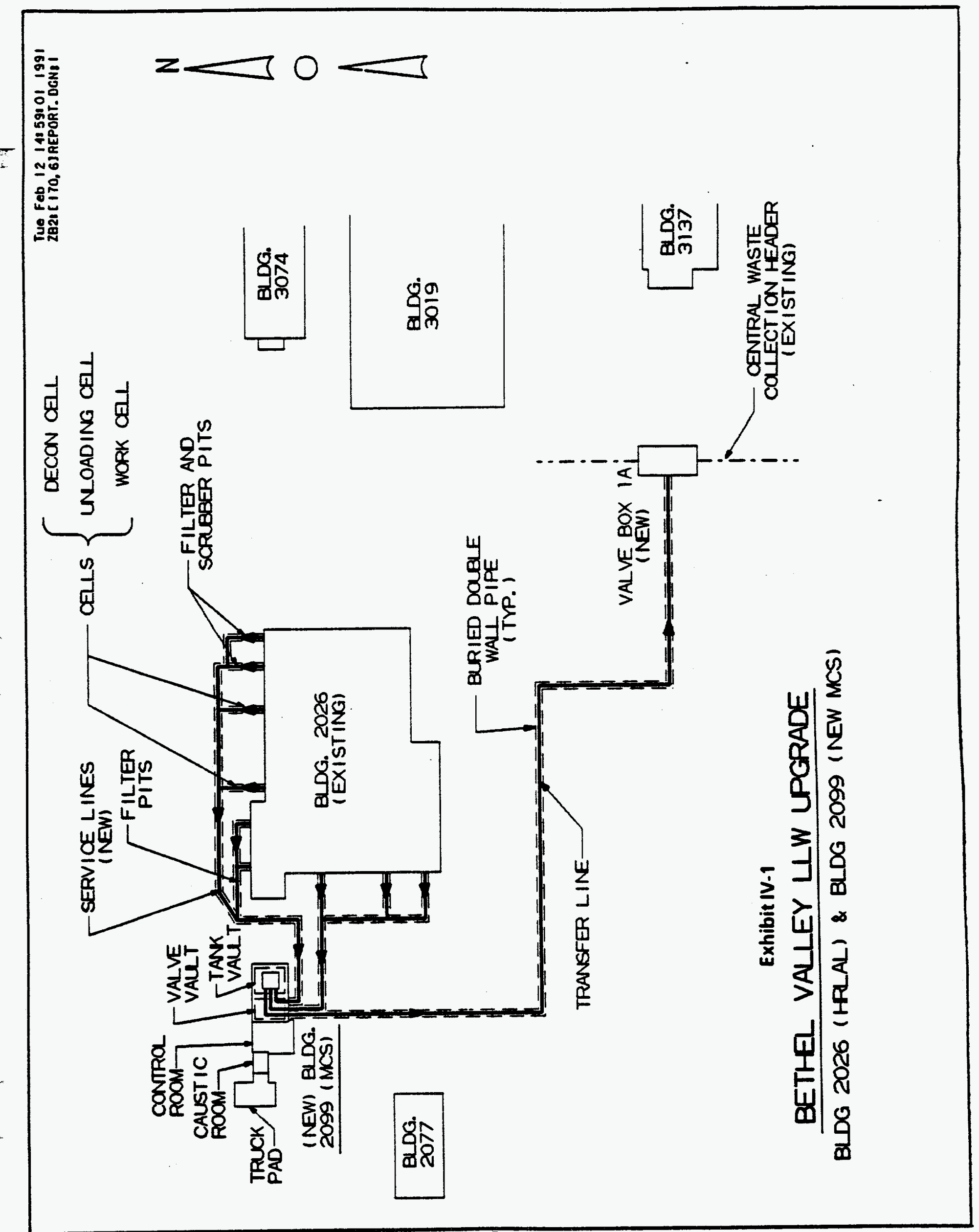




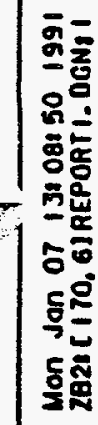

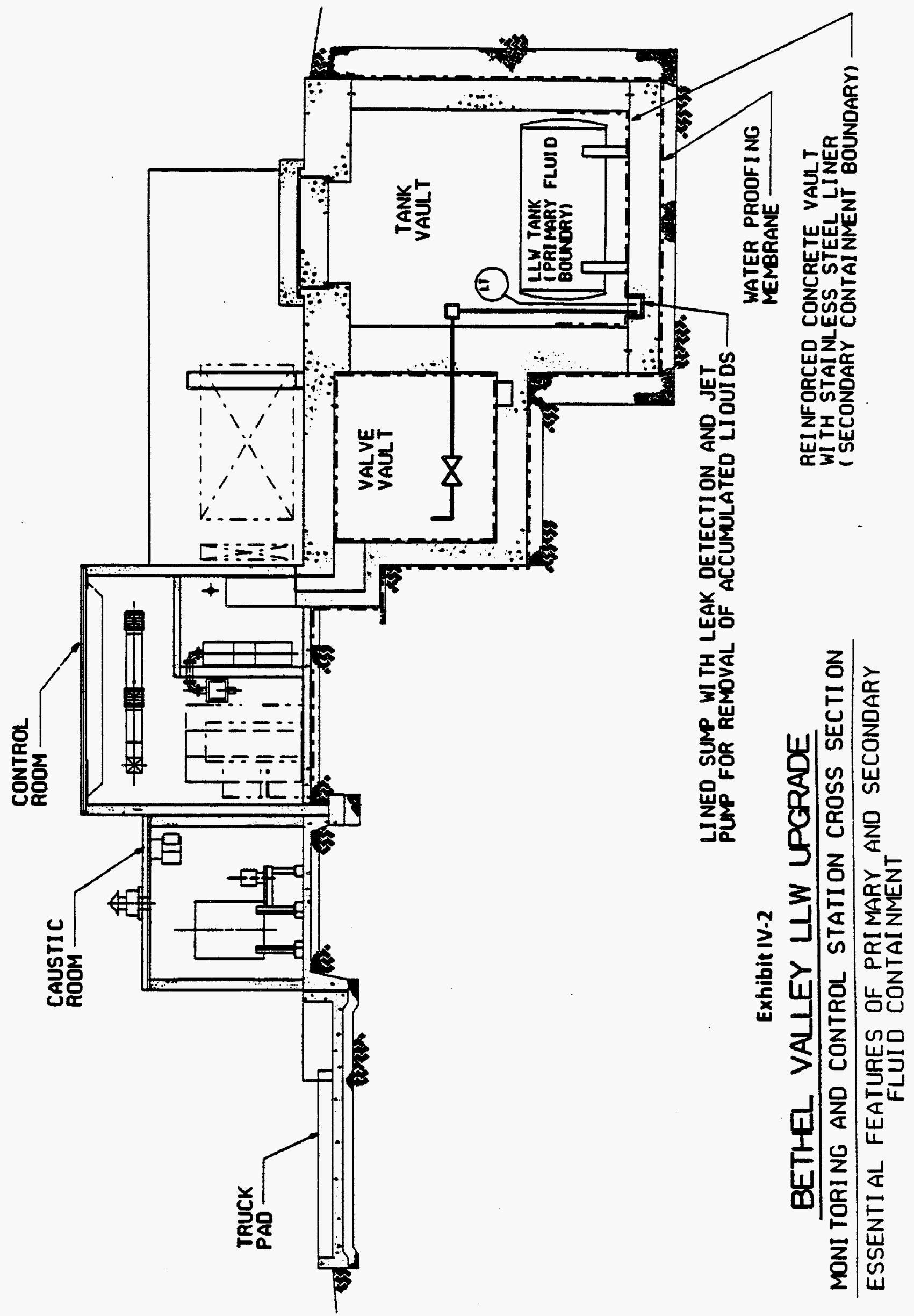


- Double wall pipe embedded in concrete or buried underground. The outer pipe fulfills the secondary containment function and is protected from corrosion by an exterior coating in conjunction with a galvanic anode type cathodic protection system. The annular space between the double wall pipe retains potential leakage from the inner, primary, waste containing pipe. The space is provided with leak detection by pressurization with nitrogen and monitoring of the annular space pressure. The annular space is divided into many discrete segments and provided with test and monitoring stations to facilitate location and repair of potential leaks.

The piping runs are classified into two functional categories:

Service piping conveys LLW from a source to the LLW tank in the MCS. A source is an individual entity such as a cell, laboratory sink, or other item that produces limited quantities of waste at discrete intervals. Most service piping is designed for gravity drainage.

Transfer piping conveys LLW from the LLW tank to the connection with the CWCH. The LLW tank may hold 1,100 or more gallons of waste, which is pumped in batches through the transfer line by a steam jet ejector during a transfer operation.

The difference in volumes of liquid handled between typical service and transfer line operation, and in the gravity versus pumped motivation of the flow, leads to different hazard classifications for the two types of piping. This, in turn, results in different levels of stringency for evaluation of seismic induced loads. This assessment concludes that this approach is acceptable in view of the different levels of potential for environmental releases.

A tank comprising a single wall LLW collection tank fabricated from corrosion resistant material and located in a buried underground reinforced concrete vault. The vault, which fulfills the secondary containment function, is provided with a stainless steel inner liner and a sump with a leak detection system. The vault is designed to withstand design basis natural phenomena, including seismic events and tornadoes. 
The overall conclusion of this assessment is that the various elements described above, which compose the entire replacement Tank System for the Building 2026/2099 complex, are in compliance with applicable portions of Appendix $F$ to the Federal Facility Agreement. The remaining portions of this assessment describe the means of compliance for each design feature and confirm the adequacy of the design for the purposes of environmental protection.

\section{B. Standards for Design/Installation of New or Replacement Tank Systems}

\section{Design/Installation Assessment}

This part of the assessment focuses on the following aspects of the replacement Tank System:

- Design standards, including codes, criteria, and specifications used by the design project for design, fabrication, and installation of the Tank System.

- Characteristics of hazardous substances to be contained by the Tank System.

- Corrosion protection provided by the design for metal components that will be in direct contact with the soil, such as the outer pipe in a double wall pipe system.

- Man-induced hazards, such as vehicular traffic.

- Natural phenomena, such as seismic events, frost heave, ground water, heavy rain and surface run-off, and potential flooding of nearby water sources (White Oak Creek).

\section{(a) Design Standards}

The applicable standards, codes, and criteria used by the design project that govern the design, fabrication, and 
installation of the tank systems are identified herein. The application of standards, codes, and criteria is generally performed on an engineering disciplinary basis and, therefore, the following listing is so organized. The list has been edited to minimize duplication, but certain entries are repeated if they constitute a key element in the input for a particular discipline work scope. The adequacy of these standards, codes, and criteria is evaluated by discipline and is correlated with specific design features when applicable.

(i) Mechanical Engineering and Design

The scope of mechanical engineering and design for the replacement tank system includes the LLW tank, all LLW containing piping (single and double wall), and support equipment such as the tank ventilation system.

The assessment concludes that the standards, codes, criteria, and specifications for the mechanical engineering aspects of the Tank System for Building 2026 and its MCS, Building 2099, are suitable and appropriate. The tank, primary and secondary piping, and other design elements are covered by codes, etc. that mandate use of appropriate materials, design, fabrication and installation, and examination and inspection procedures and techniques.

The selection of materials for the Tank System is appropriate in order to assure compatibility with the wastes to be stored. Building 2026 typically is a generator of acidic liquids. The material selected for principal portions of the primary, or inner, boundary of the new LLW service piping is Hastelloy-C, which exhibits excellent corrosion resistance in the presence of moderately strong acids. 
The LLW tank is constructed of Type 304L austenitic stainless steel, which while not as resistant as Hastelloy-C material, still exhibits good acid resistance. The LLW tank will not be exposed to the same acid concentration as will the service piping since the incoming waste streams will mix with and be diluted by the residual liquid in the LLW tank. The design of the Tank System provides for the capability to add caustic in measured amounts to adjust the pH of the tank liquid.

Limited portions of the service piping (the scrubber pit discharge); the transfer piping; and related ancillary equipment such as steam jet ejectors, HVAC ductwork and filter housings, and vault and sump liners are also fabricated from Type 304L austenitic stainless steel. The aforementioned components will not be exposed to the undiluted, unadjusted waste carried by the service piping. Therefore, the Type $304 \mathrm{~L}$ material selected is considered to be compatible with the wastes it will be exposed to.

This portion of the assessment is valid for the design and installation of the Tank System. The design is essentially complete and is in compliance with the referenced codes, standards, and criteria. During the installation phase of the project, actions such as examinations, inspections, and tests must be undertaken to confirm that the installation remains in conformance with the design and with required codes, standards, etc. 
The application of the following standards, codes, and criteria to essential elements of the design is indicated as follows:

P - applies to primary (inner) LLW containing pipe and valves

S - applies to secondary (outer) pipe

T - applies to LLW containing tanks

\section{Codes}

American Society of Mechanical Engineers (ASME)

- NQA-1, Quality Assurance Program Requirements T for Nuclear Facilities

- Boiler and Pressure Vessel Code $P, T$ Section II, Material Specifications

(Governs materials specifications in conjunction with ASTM Standards)

- Section III, Nuclear Power Plant Components Division 1, Subsection NB (Used to govern procurement of piping materials)

- Section V, Non-destructive Examination $P, S, T$ (Governs non-destructive examination in conjunction with Section VIII)

- Section VIII, Division 1, Pressure Vessels (Design code for tank) 
- Section IX, Welding and Brazing Qualifications

(Governs qualification of welders)

American National Standards Institute (ANSI)

- B16.5, Steel Pipe Flanges and Flanged Fittings

$P, S, T$

(Governs flange pressure/temperature ratings)

- B31.3, Chemical Plant and Petroleum Refinery

$P, S$

Piping (Design code for LLW piping)

\section{Standards}

American Society for Testing Materials (ASTM)

- A-182, Specification for Forged or Rolled $P, S, T$ Alloy-Steel Pipe Flanges, Forged Fittings, and Valves and Parts for High Temperature Service

- A-193, Specification for Alloy-Steel and Stainless Steel Bolting Materials for High Temperature Service

- A-194, Specification for Carbon and Alloy-Steel P, S,T Nuts for Bolts for High Pressure and High Temperature Service

- A-213, Specification for Seamless Ferritic and Austenitic Alloy-Steel Boiler-Superheater and Heat Exchanger Tubes

- A-240, Specification for Heat-Resisting Chromium T and Chromium-Nickel Stainless Steel Plate, Sheet, and Strip for Pressure Vessels 
A-262, Practices for Detecting Susceptibility to Intergrannular Attack on Austenitic Stainless Steels

- A-312, Specification for Seamless and Welded $P, S, T$ Austenitic Chromium-Nickel Alloy Steel Pipe for High Temperature Service

- A-358, Specification for Electric-Fusion-Welded Austenitic Chromium-Nickel Alloy Steel Pipe for High Temperature Service

- A-403, Specification for Wrought Austenitic P, S, T Stainless Steel Piping Fittings

- A-479, Specification for Stainless and Heat-Resisting Steel Wire, Bars, and Shapes for Use in Boilers and Other Pressure Vessels

- SB-366, Specification for Factory-Made Wrought $\mathbf{P}$ Nickel and Nickel Alloy Welding Fittings

- SB-622, Specification for Seamless Nickel and Nickel-Cobalt Alloy Pipe and Tube

- D-227, Specification for Coal-Tar Saturated $S$ Organic Felt Used in Roofing and Waterproofing

- D-450, Specification for Coal-Tar Pitch Used in Roofing, Dampproofing, and Waterproofing

American Water Works Association

- 203-86, Coal-Tar Protective Coatings and Linings $S$ for Steel Water Pipelines - Enamel and 
Tape-Hot-Applied (Governs coating on secondary pipe for corrosion protection in soil)

American Welding Society

- A5.9, Specification for Corrosion Resisting $P, S, T$ Chromium and Chromium-Nickel Steel Bare and Composite Metal Cored and Stranded Welding Electrodes and Welding Rods

- QC-1, Standard for AWS Certification of Welding P, S, T Inspectors

- SNT-TC-1A, Recommended Practice, American $P, S, T$ Society for Non-destructive Testing, Inc.

- Occupational Safety and Health Administration T Standards (OSHA)

- Uniform Building Code, 1988 T

- UCRL-15910, Design and Evaluation Guidelines $\mathrm{T}$ for DOE Facilities Subjected to Natural Phenomena Hazards

(ii) Structural Engineering and Design

The scope of structural engineering and design includes the lined, vaulted structures providing secondary containment for the LLW Tank; foundations, shield walls and covers, and flange junction boxes for the buried double wall pipe; and structural modification to the source Building 2026 to accommodate the new LLW piping. 
The use of the American Concrete Institute codes and standards for design and construction of the secondary containment concrete structures, as well as all of the other concrete structures, has been evaluated. Use of these codes and standards will assure high quality concrete structures consistent with the function of housing containment tanks and piping containing low level liquid wastes.

The loads and load combinations required by the Standard Building Code, ANSI A58.1, and UCRL 15910 are appropriate for the design of the concrete structures.

The stainless steel liner provided on internal vault surfaces functions as the leak tight secondary containment barrier. The thin liner is relatively flexible compared to the heavy, reinforced concrete vault structures backing the liner. Any minor stresses introduced into the liner through compatibility with the concrete structures are self-relieving. The primary design considerations for the liner are material selection and the installation/inspection criteria. The ASME Code Sections and ASTM standard specifications that have been used are appropriate and will result in the required quality to assure leak-tightness.

The following standards, codes, and criteria were applied to the structural design and specifications for fabrication and installation of the structural systems.

- $\quad$ Standard Building Code 1988

- Uniform Building Code 1988 (earthquake regulations) 
- $\quad$ All 318-83 (Revised 1986), "Building Code Requirements for Reinforced Concrete"

- $\quad \quad \quad A C l$ 301-84 (Revised 1987), "Specifications for Structural Concrete for Buildings"

- $\quad$ ACl 515.1R-79 (Revised 1985), "A Guide to the Use of Waterproofing, Dampproofing, Protective, and Decorative Barrier Systems for Concrete"

- $\quad \quad \quad A C l 117-81, "$ Standard Tolerances for Concrete Construction and Materials"

- $\quad$ ACl 302.1 R-80, "Guide for Concrete Floor and Slab Construction"

- $\quad \mathrm{ACl}$ 315-80, "Details and Detailing of Concrete Reinforcement"

- $\quad \mathrm{ACl}$ 347,-78, "Recommended Practice for Concrete Formwork"

- $\quad$ ACI SP-4, "Formwork for Concrete"

- $\quad A C l$ 303R-74 (Revised 1982)، "Guide to Cast-in-Place Architectural Concrete Practice"

ACl 211.1-81 (Revised 1985), "Standard Practice for Selecting Proportions for Normal, Heavyweight, and Mass Concrete" 
- $A C l$ 305R-77 (Revised 1982), "Hot Weather Concreting"

- $\quad$ ACl 306R-78 (Revised 1983), "Cold Weather Concreting"

- ACl 224R-80 (Revised 1984), "Control of Cracking in Concrete Structures"

- ACI 350R-83, "Concrete Sanitary Engineering Structures"

- American Institute of Steel Construction

- AISC "Code of Standard Practice for Steel Buildings and Bridges," effective September 1, 1986

- $\quad$ "Specification for the Design, Fabrication, and Erection of Structural Steel for Buildings," Part 1, effective Nov. 1, 1978, with Supplement 1 (March 11, 1986)

- American Society For Testing Materials (ASTM) Standards

The quality and testing of materials used in the construction was addressed by reference to the appropriate ASTM standard specifications in the project specifications and by reference in project specifications to governing standards such as $\mathrm{ACl}$ 318 or $\mathrm{ACl} 301$, which incorporate the applicable ASTM standard specifications. 
- American Welding Society Specifications and Codes

- D1.1-88, "Structural Welding Code"

- D1.3-81, "Specification for Welding Sheet Steel in Structures"

- American Society of Mechanical Engineers Boiler and Pressure Vessel Code, 1986, including 1987 Addenda

- Section V, "Non-Destructive Examination"

- Section IX, "Qualifications Standard for Welding and Brazing Procedures, Welders, Brazers, and Welding and Brazing Operations"

- American National Standards Institute

- $\quad$ ANSI A58.1 - 1982, "Minimum Design Loads for Buildings and Other Structures"

- Occupational Safety and Health Administration (OSHA) Regulations

- DOE Order 6430.1A, "General Design Criteria"

- UCRL 15910, "Design and Evaluation Guidelines for Department of Energy Facilities Subjected to Natural Phenomena Hazards," May, 1989 (Draft) 
- Steel Deck Institute

- SDI-Publication No. 24, 1981-82 (SDI 24),

"Design Manual for Composite Decks, Form Decks, and Roof Decks"

- Steel Joist Institute

- SJl, "Standard Specifications for Open Web Steel Joists, K-Series" (adopted by Steel Joist Institute Nov. 4, 1985, Revised May 19, 1987)

- Concrete Reinforcing Steel Institute MSP-1-86,

"Manual of Standard Practice," 24th Edition

- American Iron and Steel Institute (AISI), "Specification for the Design of Cold-Formed Steel Structural Members," August 19, 1986 Edition

\section{(iii) Civil/Geotechnical Design Standards}

The scope of civil/geotechnical engineering and design includes establishing plans and profiles for the underground double wall piping, the design and specification of final surface contours, backfill and paving, and the characterization of site soil properties for interfacing with foundation design.

The following listing presents standards, codes, and criteria that governed the civil and geotechnical engineering and design for the Bethel Valley LLW Upgrade Project. These standards, codes, and criteria provide a conservative basis for design and installation of the tank system, and provide assurance that loadings 
and stresses imposed upon the tank vault and the double wall buried piping will not cause collapse, rupture, or failure of these design features.

- ORNL/MMES/USDOE "Design Criteria for the Bethel Valley Liquid Low Level Waste Collection and Transfer System Upgrade Project, " issued approved September, 1988

- Subsurface soil boring logs and soil boring location plans received from MMES on March 25 , 1988 , and related subsurface investigation information received from MMES on May 11 , 1988; data on borings at or in the vicinity of Building 2026 is shown on VITRO Engineering Company drawing no. 1386- $\mathrm{H}-101$, dated September 1, 1961

- MMES Technical Specifications and Sample Specifications

- MMES Engineering Standards

- U.S. Department of Navy Design Manual, NAVFAC DM7.3, April, 1983, for maximum ground acceleration $(=0.17 \mathrm{~g})$ at underground service pipelines

- UCRL-15910, "Design and Evaluation Guidelines for Department of Energy Facilities Subjected to Natural Phenomena Hazards," draft dated May, 1989, for maximum ground acceleration at ground surface $(=0.32 \mathrm{~g})$ for underground LLW transfer pipelines and tank vault 
- ERC/EDGe Report, "Pipe Backfill Testing, Oak Ridge Reservation, Oak Ridge, Tennessee," dated June 28, 1990

- EDGe Report, "Proposed Bethel Valley Low Level Waste Project, Oak Ridge, Tennessee," dated June 22, 1988, and received September 29, 1988

- DOE General Design Criteria (DOE 6430.1A) for design basis earthquake dynamic analysis

- UCRL-53582, Rev. 1, "Natural Phenomena Hazards Modeling Project: Seismic Hazard Models for Department of Energy Sites," dated November, 1984

- Civil/Geotechnical Construction/Installation Standards (i.e., Interface Procedures):

- Tennessee Department of Transportation "Standard Specifications for Road and Bridge Construction," March 1, 1981, with revisions and additions

- U. S. Department of Labor, Occupational Safety and Health Administration (OSHA) Standards, 29CFR 1926/1910, 1987

AASHTO T180-831, "Moisture-Density Relations of Soils Using a $10 \mathrm{lb} .(4.54 \mathrm{~kg})$ Rammer and an 18-in. (457 mm) Drop"

- $\quad$ AASHTO T191-831, "Density of Soil InPlace by the Sand-Cone Method" 
- $\quad$ AASHTO T204-64 (1974), "Density of Soil In-Place by the Drive Cylinder Method" AASHTO T205-831, Density of Soil in-Place by the Rubber-Balloon Method"

- $\quad$ AASHTO T233-70, "Density of Soil In-Place by Block, Chunk, or Core Sampling"

- $\quad$ AASHTO T238-79, "Density of Soil and SoilAggregate In-Place by Nuclear Methods (Shallow Depth)"

- $\quad$ AASHTO T255-83, "Total Moisture Content of Aggregate by Drying"

- USDOE "Determination of Inorganic Anions in Aqueous and Solid Samples by Ion Chromatography", test method, latest approved version

(iv) Instruments and Controls Engineering and Design

The codes and standards listed below cover selected aspects of the instruments and controls scope of work for the Building 2026/2099 portion of the Bethel Valley LLW Upgrade. These codes and standards are appropriate and adequate to govern the design and installation of design features necessary for compliance with 40CFR264, Subpart J. These design features comprise the level detection and leak detection provisions for the LLW tank, secondary containment vault sumps, and the annular spaces in buried double wall piping. 


\section{Codes}

National Fire Protection Association (NFPA)

- NFPA 70-1990, National Electric Code (NEC)

American Welding Society (AWS)

- D1.3.81, Structural Welding Code - Sheet Steel

- D1.1.88, Structural Welding Code

\section{Standards}

American National Standards Institute (ANSI)

- B16.1 1-80, Fittings, Socket-Welded, and Threaded

- B31.3-87, Chemical Plant and Petroleum Refinery Piping

\section{- C2, National Electrical Safety Code}

Instrument Society of America (1SA)

- ISA-S5.1-1984, Instrumentation Symbols and Identification

- ISA-S5.4-1976 (R-81), Instrument Loop Diagrams

- ISA-RP7.1-1956, Pneumatic Control Circuit Pressure Test

- ISA-S12.13-1986, Performance Requirements, Combustible Gas Detectors 
- ISA-S20-1981, Specification Forms for Process Measurement and Control Instrument

- ISA-S51.1-1979, Process Instrumentation

National Electrical Manufacturer's Association (NEMA)

- 250-85, Enclosures

- 1CS-6-83, Enclosures for Industrial Controls

- 1CS-1-83, General Standards

- WC-5, Thermoplastic Insulated Wire and Cable

- WC-7, Cross-linked Thermosetting Polyethylene Insulated Wire and Cable

- WC8, Ethylene-Propylene Rubber Insulated Wire and Cable

(v) Electrical Engineering and Design (Cathodic Corrosion Protection)

The standard listed below covers the design, installation, and testing of cathodic protection systems for buried metallic components. The use of this standard is appropriate to provide satisfactory corrosion protection for the buried double wall pipe (outer pipe in contact with soil). No tanks are directly in contact with the soil.

Certain other codes and standards that are required to assure the adequate design and installation of level and leak detection systems are listed in the Instruments and Controls Section. 
- RP-01-69, 1983, Recommended Practice - Control of External Corrosion on Underground or Submerged Metallic Piping Systems

\section{IV.B.1(b) Hazardous Substance Characteristics}

The hazardous and/or radioactive substances handled by Building 2026 and discharged into the Building 2099 MCS for eventual transfer to the ORNL CWCH are listed in Table B-1. This characterization is based on assessments of facility mission requirements and historical knowledge of previous waste stream properties, and is provided by Martin Marietta Energy Systems (ORNL Operating Contractor) as input to this assessment.

It is expected that the waste stream analysis presented in Table B-1 is representative of the waste to be received by the tank in MCS Building No. 2099. However, the composition of this waste stream may vary as specific experiments, analyses, and campaigns are conducted. Of principal concern for this assessment is the suitability of the material selected as the primary fluid boundary for piping exposed to unadjusted, undiluted waste. In this regard, the $\mathrm{pH}$ value as a measure of acidity and aggressiveness is of principal interest. The suitability of primary fluid boundary materials is discussed in IV.B. 1.(a)(i) of this assessment.

The variations in composition of the waste stream are limited by the General Waste Acceptance Criteria, which specifies activity and concentration limits for waste discharged in to the LLW system. These criteria are presented below: 


\section{Waste Acceptance Criteria}

The LLW system should be used to collect and treat all solutions containing radioactivity above the levels listed in Table B-2, with the following provisions:

- Liquid radioactive wastes added to the LLW system must not have an activity concentration exceeding $5 x$ $1010 \mathrm{~Bq} / \mathrm{L}$ (5ci/gal).

- Solutions containing 233U, 235U, 235Pu, or $241 \mathrm{Pu}$ must be mixed with depleted uranium or natural thorium so that the resultant solution will contain at least 100 parts by weight of 238U or 232Th per part by weight of the fissile isotope(s).

- Solutions containing TRU isotopes of $233 \mathrm{U}$ that are added to the LLW system must not have a total specific activity from those nuclides greater than $3.7 \times 106 \mathrm{~Bq} / \mathrm{kg}$ $(100 \mathrm{nCi} / \mathrm{g})$.

- Beta-gamma emitting waste greater than $5 \times 1010 \mathrm{~Bq} / \mathrm{L}$ ( $5 \mathrm{Ci} / \mathrm{gal}$ ) and high toxicity alpha and TRU waste greater than $3.7 \times 106 \mathrm{~Bq} / \mathrm{kg}(100 \mathrm{nCi} / \mathrm{g})$ must be diluted to levels below those limits prior to discharge.

- Before disposing of liquid waste containing reportable nuclear material, the generator must execute Form $U \mathrm{CN}-6073$ to request and receive permission from the Special Materials Management Department. Reportable quantities of nuclear material are listed in Health Physics Procedure 5.3, page 7, Table 2. The generator prepares Form UCN-2681 to complete the transfer of the reportable nuclear material to either the Liquid and Gaseous Waste Operations Department or the Solid Waste Operations Department. 
Table B-1

BETHEL VALLEY LIQUID LOW LEVEL WASTE

STREAM CHARACTERIZATIONS

BUILDING 2026 - HIGH RADIATION LEVEL ANALYTICAL LABORATORY

Substance

Ref. Number

Gross Beta (Bq/ml)

Gross Alpha (Bq/ml)

SR-90 (Bq/ml)

Spec. Gravity

$\mathrm{pH}$

$\mathrm{H}+$ normality

Total Solids ( $g / l)$

Diss. Solids ( $g / l)$

UP Data (ug/ml):

Request Number

Silver

Aluminum

Arsenic

Boron

Barium

Beryllium

Calcium

Cadmium

Cobalt

Chromium

Copper

Iron

Gallium

Hafnium

Potassium

Lithium

Magnesium

Manganese

Molybdenum

Sodium

Nickel

Phosphorus

Lead

Antimony

Selenium

Silicon

Strontium

Titanium

Vanadium

Zinc

Zirconium

Anions:

Nitrate
Data

34461

$6.0 E+05$

ND

$2.3 E+05$

1.0076

3.0

1.2

1.2

53333

$<25$

$<100$

$<50$

$<40$

$<11$

$<1$

1800

3.9

$<5$

$<20$

54

$<15$

$<150$

ND

ND

$<100$

330

$<2.5$

$<20$

2000

30

$<150$

$<100$

$<100$

$<100$

370

3

$<10$

5

12

$<10$

ND 
GROSS ALPHA

GROSS BETA

Sr-90

Cs-137

Co-60

Eu-152

Eu-154

Eu-155

Ru-106

ZrNb-95
10Bq/L

$10,000 \mathrm{~Bq} / \mathrm{L}$

$10,000 \mathrm{~Bq} / \mathrm{L}$ $400 \mathrm{~Bq} / \mathrm{L}$ $185 \mathrm{~Bq} / \mathrm{L}^{*}$

$740 \mathrm{~Bq} / \mathrm{L}^{*}$

$740 \mathrm{~Bq} / \mathrm{L}^{*}$

$3700 \mathrm{~Bq} / \mathrm{L}^{*}$

$222 \mathrm{~Bq} / \mathrm{L}^{*}$

$1,480 \mathrm{~Bq} / \mathrm{L}^{*}$

* DOE order 5400.5 DCG values

LLW, which also contains toxic materials (PCB's, mercury, etc.), should not be discharged to the LLW system (unless a waiver is granted by Waste Management Operations), but should be transferred to the Hazardous Waste Operations Group for storage until its ultimate disposition is determined. Organic solvents or organic chemicals contaminated with radioactivity may be discharged into LLW drains provided the primary hazard of concern is radioactivity. Sanitary waste must not be discharged to the LLW system unless a medical emergency exists.

No new LLW streams greater than $15 \mathrm{gpd}$ in volume are to be added without the permission of the Liquid Waste LCO.

\section{IV.B.1(c) Corrosion Protection}

The replacement Tank System design for the Building 2026/2099 complex does not expose the external shell of any metal tanks to direct contact with the soil or with water. As noted previously, the waste (LLW) tank is located in an underground, lined, concrete vault. However, a significant 
amount of buried piping constitutes an important part of the design. This buried piping is in direct contact with a backfill material selected to provide favorable design properties, as discussed in Section IV.B.4 and IV.B.6 of this assessment.

Norton Corrosion Limited, Inc., under subcontract to the Architect/Engineer, has reviewed original soil data (provided by Martin Marietta Energy Systems), engineered backfill characteristics, pertinent design drawings and specifications, and design calculations to ensure pertinent criteria have been met. This includes providing a system that requires minimal maintenance and meets the design criteria life requirements. The specific criteria used have been assessed with the results as follows:

(i) Soil Corrosion Factors

Soil data was reviewed and offered an adequate representation of the soil characteristics throughout the piping routes. In addition, characteristics of the piping backfill were provided and included in the design calculations. This design provides relatively controlled environmental conditions, due to the use of an engineered backfill material to be installed in a prescribed manner. This increases the confidence level in the expected performance of the entire corrosion protection system.

A review of pertinent electrical drawings was conducted to determine possible sources of potentially damaging current interference. This includes high voltage power lines, other cathodic protection systems, or dc power sources. The results of this review found no immediate concerns. It should be noted that the postinstallation testing will test for current interference. 
(ii) External Corrosion Protection

A number of corrosion control measures have been implemented. Specifically, the outer (secondary) containment pipe of the double wall LLW pipe system utilizes a 304-L stainless steel alloy. In addition, a high dielectric coating will be applied to isolate the piping from the backfill and surrounding soil. Since no coating system is $100 \%$ effective, a galvanic cathodic protection system is provided to protect any exposed metal. A review of these systems found that they are properly designed and meet all design criteria.

Electrical isolation of the piping is provided to maintain the integrity of the corrosion control systems. This includes isolation of the new piping from new and existing structures, leak monitoring equipment, and concrete vault penetrations. The materials and methods used include flange isolation kits and non-metallic grounding cells provided at all isolation flanges to prevent hazardous shorting conditions from developing.

In order to test and confirm the proper operation of the cathodic protection system following installation, a number of test stations are provided. These test stations utilize copper-copper sulfate reference electrodes, which provide a reference for the measurement of electric potentials between the pipe and the soil (backfill). The performance of the cathodic protection system shall be checked and documented after installation by an N.A.C.E. certified engineer.

Final design calculations (Ref: DC-5350-01-E01) indicate a life expectancy of 125 years, compared to the original design criteria requirement of 25 years. Therefore, this 
assessment concludes that the corrosion protection system employed for the outer pipe of the buried double wall piping is satisfactory for its intended purpose.

\section{IV.B.1(d) Vehicular Traffic Protection}

(i) MCS:

The edge of an existing low volume, asphalt paved roadway will range from approximately 7 to 14 feet in distance from the outside wall of the reinforced concrete tank vault pit. Conservatively assuming a $45^{\circ}$ zone of influence from an $\mathrm{H} 20$ truck live load (plus impact) located 7 feet from the tank vault pit wall, this load would influence the wall at a minimum depth of 7 feet by imposing a vertical surcharge load of approximately 200 psf. This will be the maximum value and would be imposed at the southeast corner of the tank vault pit. The vertical surcharge load would vary, with a minimum value occurring at the bottom of the pit, of approximately 50 psf. The tank vault walls are designed for a surcharge load of 250 psf, placed over the entire ground surface at the walls. Thus, the design load exceeds the vehicular load described above, as well as vehicular loads anticipated during construction.

(ii) LLW Underground Piping:

The radiation shielding requirement necessitates a minimum earth cover of 3 feet above all LLW underground piping. Therefore, the piping is designed for a vertical load on the pipe equivalent to at least 6 feet of soil, which is twice the minimum earth cover.

The backfill around the pipe will consist of sandbentonite mixture placed in 6-inch layers and 
compacted using light (hand-held) compaction equipment.

As the (outer) pipe diameter of 4 inches is small compared to the minimum 3-foot embedment and as the pipe wall will be Schedule 10 stainless steel, the pipe can be considered flexible with respect to the compact backfill around it. Also, due to the pipe flexibility and small diameter, the load imposed on it due to vehicular traffic at grade surface will be negligible. Due to light compaction equipment, the vertical load(s) imposed on the pipe will be smaller during construction than the design load. Thus, the pipe is designed conservatively with respect to vehicular or equipment loads during or after construction.

\section{IV.B.1(e) Design Considerations}

(i) The tank is housed in an underground reinforced concrete vault structure. The tank foundation consists of a 20-foot by 19 -foot by 2 -foot thick reinforced concrete vault base slab.

The tank vault arrangement has the bottom of the base slab approximately 23 feet below finished grade. The base slab is founded on rock. A concrete mud mat is provided over the rock to accept the base slab. Due to the below grade embedment of the tank vault, the net maximum bearing pressure on the rock is less than $1 \mathrm{ksf}$, well within the permissible bearing capacity of the rock. Due to the very low vault bearing pressure relative to the rock bearing capacity, settlement of the tank vault is expected to be insignificant.

The assessment concludes that the tank foundation is conservatively designed to maintain the load of a full tank. 
(ii) The LLW tank design includes the provision of anchorage for the tank to the base slab. The anchorage has been designed for two loading conditions: Seismic loading assuming the tank is full, which is the controlling seismic condition, and flotation or buoyancy forces on the tank assuming the tank is empty and the tank vault is filled with water.

The tank is provided with two saddle supports. Each saddle is supported on a separate base plate that is anchored to the base slab. The base plate also functions as part of the secondary containment liner.

The loadings, load combinations, and permissibles comply with UCRL 15910 for the high hazard classification. The maximum horizontal ground surface acceleration used in the design is $0.32 \mathrm{~g}$, which corresponds to a hazard annual probability of exceedance of 2x10-4 for ORNL (Ref UCRL 15910, Table 4-3). Since the tank is anchored to the base slab of the below grade vault, seismic loads for the design of the tank anchorage correspond to use of the peak value from the median centered Newmark and Hall response spectrum for a competent soil site anchored at $0.32 \mathrm{~g}$, assuming $5 \%$ equipment damping. The resulting peak horizontal acceleration is $0.68 \mathrm{~g}$. Directional components are combined by using the maxima response in one direction plus $40 \%$ of the maxima from the other two directions. In addition, UCRL 15910 permits use of $80 \%$ of the motion from the second horizontal direction and $60 \%$ of the peak acceleration for the vertical direction when peak response spectra accelerations are used. The anchors are designed in compliance with $\mathrm{ACl} 349$ Appendix B, "Steel Embedments," to assure a ductile failure mode. This 
design has been evaluated and found to comply with the pertinent standards, UCRL 15910 and UCRL 53582.

The assessment concludes that the LLW tank is adequately anchored to prevent flotation or dislodgement due to the potential intrusion of water into the tank vault or the occurrence of postulated seismic events.

Buried LLW piping is provided with a minimum equivalent of 3 feet of soil overburden, which provides sufficient net downward force on the 4-inch diameter pipe to preclude flotation of the LLW pipe, conservatively assuming that the pipe is buried within a saturated zone.

The buried LLW piping is routed flexibly to minimize the effects of building displacements and seismic soil strains that result from the propagation of compression, shear, and body waves associated with the design earthquake. The restraining effects of the compacted backfill and the beneficial effects of friction at the pipe/soil interface are considered conservatively in order to calculate the combined bending and axial stresses in buried elbows and branch connections and to demonstrate that the stress levels are within the limits set by ASME B31.3.

The assessment concludes that the buried double wall piping is designed to preclude displacement or damage due to the presence of groundwater or the occurrence of seismic events.

(iii) The tank vault is embedded approximately 23 feet below finished grade and is founded on rock. The average annual frost penetration, according to the Standard Building Code, is less than 10 inches for the 
ORNL. Therefore, frost heave will not affect the tank vault.

Similarly, all LLW pipes are buried with a minimum equivalent of 3 feet of soil overburden over the pipe and, therefore, are also unaffected by frost.

\section{IV.B.2. Tank Systems Installation}

The procedure for handling buried double wall pipe and the LLW tank, from the time of receipt on site, up to and including lowering of the piping into the trench and lowering the tank into the tank vault, will be reviewed by a qualified installation inspector. During fabrication and construction of the Tank System, primary inspection of welds in the tank, piping, liners, etc. will be performed by MMES AWS-Certified welding inspectors. Inspection of concrete, rebar, waterproofing, etc. will be performed by qualified MMES construction engineers.

The installation inspector will observe the installation of the piping and tank and will visually inspect the completed installation for the presence of weld breaks, punctures, scrapes of protective coatings, cracks, corrosion, or other structural damage or inadequate construction/installation. Design engineers from MMES and the Architect/Engineer (Gilbert/Commonwealth, Inc.) will consult with construction engineers, MMES QA personnel, and construction personnel, and will audit installation records to confirm compliance with design provisions.

The detection and remediation of scrapes of protective coatings applies to the coating provided on the outside of the secondary (outer) pipe. The procedure aimed at assuring the integrity of this coating system is based on the requirement of a visual holiday inspection just prior to lowering the pipe into the excavation. Defects will be repaired and rechecked prior to final installation and backfill of the pipe. 
It should be noted that due to the provision of a cathodic protection system for pipe buried in soil (engineered backfill), (see Sections B. 1(c), B7, and B. 8 of this assessment), the presence of small defects in the coating system, although not desirable, will not compromise the long term integrity of the system.

The remainder of this section summarizes the measures that must be undertaken during the fabrication, installation, and testing of the Tank System prior to placing the system in service. These measures are included in the technical specifications governing the design, fabrication, and installation of the Tank System, and are presented in summary form in the following Installation Assessment Summary. 


\section{INSTALLATION ASSESSMENT SUMMARY}

\begin{tabular}{|c|c|c|}
\hline $\begin{array}{c}\text { Assessment Action } \\
\text { Required }\end{array}$ & By Whom & When \\
\hline $\begin{array}{l}\text { Approve subgrades/ } \\
\text { bottom of excavations for } \\
\text { building and tank vault } \\
\text { foundations. }\end{array}$ & $\begin{array}{l}\text { MMES } \\
\text { Construction } \\
\text { Engineer }\end{array}$ & $\begin{array}{l}\text { Prior to placing fill or } \\
\text { mud mat over subgrade/ } \\
\text { bottom of excavation. }\end{array}$ \\
\hline $\begin{array}{l}\text { Approve subgrades for } \\
\text { slabs, pipe, and pavements }\end{array}$ & $\begin{array}{l}\text { MMES } \\
\text { Construction } \\
\text { Engineer }\end{array}$ & $\begin{array}{l}\text { Prior to placing any fill } \\
\text { over subgrade. }\end{array}$ \\
\hline $\begin{array}{l}\text { Review results of backfill } \\
\text { density, moisture, and } \\
\text { chloride/sulfate content } \\
\text { laboratory tests. }\end{array}$ & $\begin{array}{l}\text { MMES } \\
\text { Construction } \\
\text { Engineer }\end{array}$ & $\begin{array}{l}\text { Prior to placing backfill } \\
\text { around buried pipe and } \\
\text { beneath or around below } \\
\text { grade structures. }\end{array}$ \\
\hline $\begin{array}{l}\text { Observe backfill mixing } \\
\text { and placement. }\end{array}$ & $\begin{array}{l}\text { MMES } \\
\text { Construction } \\
\text { Engineer }\end{array}$ & $\begin{array}{l}\text { During mixing and } \\
\text { placement of backfill } \\
\text { around buried pipe and } \\
\text { beneath or around below } \\
\text { grade structures. }\end{array}$ \\
\hline $\begin{array}{l}\text { Review results of in-place } \\
\text { density and moisture } \\
\text { content tests for } \\
\text { subgrades and backfills. }\end{array}$ & $\begin{array}{l}\text { MMES } \\
\text { Construction } \\
\text { Engineer }\end{array}$ & $\begin{array}{l}\text { As required and during } \\
\text { placement of fill. }\end{array}$ \\
\hline $\begin{array}{l}\text { Review certification } \\
\text { documents for concrete } \\
\text { and associated materials } \\
\text { including: cement, } \\
\text { aggregates, admixtures, } \\
\text { water, unit weight of } \\
\text { concrete, curing } \\
\text { compound, form release } \\
\text { agent, concrete sealer, } \\
\text { concrete hardener/sealer, } \\
\text { grout. }\end{array}$ & $\begin{array}{l}\text { MMES Design } \\
\text { Engineer }\end{array}$ & $\begin{array}{l}\text { Prior to initial concrete } \\
\text { production. }\end{array}$ \\
\hline $\begin{array}{l}\text { Review concrete mix } \\
\text { design test reports. }\end{array}$ & $\begin{array}{l}\text { MMES Design } \\
\text { Engineer }\end{array}$ & $\begin{array}{l}\text { Prior to initial concrete } \\
\text { production. }\end{array}$ \\
\hline $\begin{array}{l}\text { Review test results for } \\
\text { chloride content in } \\
\text { concrete. }\end{array}$ & $\begin{array}{l}\text { MMES Design } \\
\text { Engineer }\end{array}$ & $\begin{array}{l}\text { Prior to initial concrete } \\
\text { production. }\end{array}$ \\
\hline
\end{tabular}


INSTALLATION ASSESSMENT SUMMARY

\begin{tabular}{|c|c|c|}
\hline $\begin{array}{c}\text { Assessment Action } \\
\text { Required }\end{array}$ & By Whom & When \\
\hline $\begin{array}{l}\text { Review concrete supplier's } \\
\text { current NRMCA } \\
\text { certification. }\end{array}$ & $\begin{array}{l}\text { MMES Design } \\
\text { Engineer }\end{array}$ & $\begin{array}{l}\text { Prior to initial concrete } \\
\text { production. }\end{array}$ \\
\hline Review batch tickets. & $\begin{array}{l}\text { MMES } \\
\text { Construction } \\
\text { Engineer }\end{array}$ & $\begin{array}{l}\text { After each day of } \\
\text { concrete placement. }\end{array}$ \\
\hline $\begin{array}{l}\text { Review concrete pre- } \\
\text { placement inspection } \\
\text { forms, and composite } \\
\text { opening and embedment } \\
\text { schedules. }\end{array}$ & $\begin{array}{l}\text { MMES } \\
\text { Construction } \\
\text { Engineer }\end{array}$ & $\begin{array}{l}\text { Prior to each concrete } \\
\text { placement. }\end{array}$ \\
\hline $\begin{array}{l}\text { Review certifications for } \\
\text { reinforcing steel material } \\
\text { and gasket material for } \\
\text { access hatches. }\end{array}$ & $\begin{array}{l}\text { MMES Design } \\
\text { Engineer }\end{array}$ & Prior to installation. \\
\hline $\begin{array}{l}\text { Inspect reinforcing steel } \\
\text { for grade, number, size, } \\
\text { spacing of bars; adequacy } \\
\text { of support ties, splices; } \\
\text { clearances to formwork, } \\
\text { subgrade, and between } \\
\text { bars; cleanliness. }\end{array}$ & $\begin{array}{l}\text { MMES } \\
\text { Construction } \\
\text { Engineer }\end{array}$ & $\begin{array}{l}\text { Prior to each concrete } \\
\text { placement. }\end{array}$ \\
\hline $\begin{array}{l}\text { Review shop detail and } \\
\text { installation drawings for } \\
\text { stainless liners, gaskets, } \\
\text { reinforcing steel, and } \\
\text { membrane waterproofing. }\end{array}$ & $\begin{array}{l}\text { MMES Design } \\
\text { Engineer }\end{array}$ & Prior to fabrication. \\
\hline $\begin{array}{l}\text { Review qualification } \\
\text { certifications of } \\
\text { procedures and welders to } \\
\text { ASME Code Section IX } \\
\text { requirements for stainless } \\
\text { steel liners. }\end{array}$ & $\begin{array}{l}\text { MMES } \\
\text { Quality Dept. } \\
\text { (AWS } \\
\text { Qualified } \\
\text { Weld } \\
\text { inspector) }\end{array}$ & $\begin{array}{l}\text { Prior to performance of } \\
\text { work. }\end{array}$ \\
\hline $\begin{array}{l}\text { Review installation } \\
\text { instructions for gaskets } \\
\text { and membrane } \\
\text { waterproofing. }\end{array}$ & $\begin{array}{l}\text { MMES Design } \\
\text { Engineer }\end{array}$ & Prior to field installation. \\
\hline $\begin{array}{l}\text { Review manufacturer } \\
\text { certification of membrane } \\
\text { waterproofing applicator. }\end{array}$ & $\begin{array}{l}\text { MMES Design } \\
\text { Engineer }\end{array}$ & $\begin{array}{l}\text { As part of acceptance of } \\
\text { proposed waterproofing } \\
\text { system. }\end{array}$ \\
\hline
\end{tabular}




\section{INSTALLATION ASSESSMENT SUMMARY}

\begin{tabular}{|c|c|c|}
\hline $\begin{array}{c}\text { Assessment Action } \\
\text { Required }\end{array}$ & By Whom & When \\
\hline $\begin{array}{l}\text { Certification of membrane } \\
\text { waterproofing adherence } \\
\text { test to concrete substrate. }\end{array}$ & $\begin{array}{l}\text { MMES Design } \\
\text { Engineer }\end{array}$ & Prior to field installation. \\
\hline $\begin{array}{l}\text { Review the results of the } \\
\text { concrete compressive } \\
\text { strength cylinder break } \\
\text { test. }\end{array}$ & $\begin{array}{l}\text { MMES } \\
\text { Construction } \\
\text { Engineer }\end{array}$ & $\begin{array}{l}\text { Within one week after } \\
\text { results are submitted. }\end{array}$ \\
\hline $\begin{array}{l}\text { Review the results of } \\
\text { slump, air content, and } \\
\text { temperature tests. }\end{array}$ & $\begin{array}{l}\text { MMES } \\
\text { Construction } \\
\text { Engineer }\end{array}$ & $\begin{array}{l}\text { Daily during concrete } \\
\text { placement. }\end{array}$ \\
\hline $\begin{array}{l}\text { Review Certified Material } \\
\text { Test Reports submitted by } \\
\text { supplier of piping } \\
\text { materials for primary and } \\
\text { secondary piping, steam } \\
\text { jet ejectors, and vault liner } \\
\text { materials. }\end{array}$ & $\begin{array}{l}\text { MMES } \\
\text { Quality Dept. } \\
\text { personnel }\end{array}$ & $\begin{array}{l}\text { Upon receipt, prior to } \\
\text { fabrication and } \\
\text { installation of piping, } \\
\text { liners, etc. }\end{array}$ \\
\hline $\begin{array}{l}\text { Review Certified Material } \\
\text { Test Reports submitted by } \\
\text { LLW tank vendor. }\end{array}$ & $\begin{array}{l}\text { MMES } \\
\text { Quality Dept. } \\
\text { personnel }\end{array}$ & $\begin{array}{l}\text { Prior to start of tank } \\
\text { fabrication. }\end{array}$ \\
\hline $\begin{array}{l}\text { Review piping and vault } \\
\text { liner weld examination } \\
\text { records (required per } \\
\text { Tables B.3-1 and B.3-2). }\end{array}$ & $\begin{array}{l}\text { MMES } \\
\text { Quality Dept. }\end{array}$ & $\begin{array}{l}\text { Ongoing during } \\
\text { installation of piping and } \\
\text { vault liners. To be } \\
\text { complete prior to } \\
\text { conducting pressure test } \\
\text { for any segment of } \\
\text { piping and prior to } \\
\text { installing tank in vault. }\end{array}$ \\
\hline $\begin{array}{l}\text { Review LLW tank weld } \\
\text { examination records (per } \\
\text { Tables B.3-1 and B.3-2). }\end{array}$ & $\begin{array}{l}\text { MMES } \\
\text { Quality Dept. }\end{array}$ & $\begin{array}{l}\text { Following completion of } \\
\text { tank fabrication, prior to } \\
\text { ASME Code pressure test. }\end{array}$ \\
\hline $\begin{array}{l}\text { Review piping pressure } \\
\text { test records (refer to } \\
\text { Section IV.B.5 of this } \\
\text { assessment). }\end{array}$ & $\begin{array}{l}\text { MMES } \\
\text { Quality Dept. }\end{array}$ & $\begin{array}{l}\text { Following completion of } \\
\text { pressure test, prior to } \\
\text { covering pipe in pipe } \\
\text { trench or pouring } \\
\text { concrete (for embedded } \\
\text { pipe). May be } \\
\text { accomplished by segment } \\
\text { or portion of piping } \\
\text { system that can be } \\
\text { isolated. }\end{array}$ \\
\hline
\end{tabular}


INSTALLATION ASSESSMENT SUMMARY

\begin{tabular}{l|l|l}
\multicolumn{1}{c|}{$\begin{array}{c}\text { Assessment Action } \\
\text { Required }\end{array}$} & By Whom & \multicolumn{1}{|c}{ When } \\
\hline $\begin{array}{l}\text { Review LLW tank pressure } \\
\text { test records. }\end{array}$ & $\begin{array}{l}\text { MMES } \\
\text { Quality Dept. }\end{array}$ & Prior to shipment. \\
\hline $\begin{array}{l}\text { Review Form U-1, } \\
\text { Manufacturers Data } \\
\text { Report For Pressure } \\
\text { Vessels. }\end{array}$ & $\begin{array}{l}\text { MMES } \\
\text { Quality Dept. }\end{array}$ & Prior to Shipment. \\
\hline $\begin{array}{l}\text { Conduct final visual } \\
\text { inspection of LLW pipe } \\
\text { system, LLW tank and } \\
\text { vault liner (inspect for } \\
\text { weld breaks, punctures, } \\
\text { scrapes of protective } \\
\text { coatings, cracks, corrosion, } \\
\text { or other structural } \\
\text { damage or inadequate } \\
\text { construction/installation). }\end{array}$ & $\begin{array}{l}\text { MMES } \\
\text { Quality Dept. }\end{array}$ & $\begin{array}{l}\text { Prior to backfill of pipe } \\
\text { segment(s) and prior to } \\
\text { lowering tank into vault } \\
\text { and installing vault } \\
\text { cover. }\end{array}$ \\
$\begin{array}{l}\text { Inspection of cathodic } \\
\text { protection system for } \\
\text { buried piping - Includes } \\
\text { visual confirmation of } \\
\text { anode wire placement in } \\
\text { pipe trench, continuity } \\
\text { tests of cathodic } \\
\text { protection circuits, } \\
\text { measurement of pipe to } \\
\text { soil potentials. }\end{array}$ & $\begin{array}{l}\text { N.A.C.E. } \\
\text { qualified } \\
\text { corrosion } \\
\text { expert }\end{array}$ & $\begin{array}{l}\text { Prior to backfill of pipe } \\
\text { trench (pipe to soil } \\
\text { potential measured after } \\
\text { backfilling). }\end{array}$ \\
& & \\
& &
\end{tabular}


INSTALLATION ASSESSMENT SUMMARY

\begin{tabular}{|c|c|c|}
\hline $\begin{array}{c}\text { Assessment Action } \\
\text { Required }\end{array}$ & By Whom & When \\
\hline $\begin{array}{l}\text { Witness or review } \\
\text { documented results of } \\
\text { functional testing for Tank } \\
\text { System ancillary } \\
\text { equipment, including: } \\
\text { - Level instrumentation } \\
\text { in sumps and tanks } \\
\text { - Pressure } \\
\text { instrumentation for } \\
\text { double-wall piping } \\
\text { annular space } \\
\text { - Steam jet ejector } \\
\text { capability to remove } \\
\text { liquid from sumps and } \\
\text { tanks } \\
\text { - Combustible gas } \\
\text { detector operation } \\
\text { - LLW tank and vault } \\
\text { ventilation system }\end{array}$ & $\begin{array}{l}\text { MMES } \\
\text { Design } \\
\text { Engineer }\end{array}$ & $\begin{array}{l}\text { Prior to placing Tank } \\
\text { System into } \\
\text { contaminated service. }\end{array}$ \\
\hline
\end{tabular}




\section{IV.B.3. Inspection Reports}

The installation of the Building 2026/2099 Tank System utilizes a comprehensive and stringent set of inspections to assure the leaktight integrity of the Tank System, following installation. These include inspections of shop and field welds in LLW primary and secondary piping and in the stainless steel vault liners, in accordance with Table B.3-1. The tank is designed, fabricated, and stamped in accordance with the ASME Boiler and Pressure Vessel Code, Section VIII, Div. 1. This code requires qualified and documented weld examination procedures. The installation assessment will include reviews of weld examination records, pressure test records, material certifications, ASME Code data forms, and on-site walkdowns and visual inspections of essential portions of the Tank System.

The weld examinations noted above, in conjunction with a thorough visual examination of the entire system, provide assurance that potential weld breaks, punctures, cracks, and corrosion will be detected and remedial work undertaken prior to closure of the system, i..e, embedding in concrete, burial in fill, or installation of cover slabs. Welding inspectors shall be certified by AWS QC-1.

MMES will maintain a retrievable file of inspection reports, test records, and other pertinent documentation. A listing of required inspection reports follows in Table B.3-2. These reports, records, etc. will be reviewed, on a statistical sample basis, by the Installation Assessment team, to assure that acceptable welds have been produced. 
TABLE B.3-1

WELD INSPECTION SUMMARY

\begin{tabular}{|c|c|c|c|c|c|}
\hline Number & Title & $\begin{array}{l}\text { Visual } \\
\text { (1) }\end{array}$ & $\begin{array}{c}100 \% \\
\text { Radiography } \\
\text { (2) }\end{array}$ & $\begin{array}{c}\text { Dye Pen } \\
\text { First Pass } \\
\text { (3) }\end{array}$ & $\begin{array}{l}\text { Dye Pen } \\
\text { Last Pass } \\
\text { (3) }\end{array}$ \\
\hline Subsection 4.740 & Stainless Steel Vault Liner & $x$ & & & $x$ \\
\hline Subsection 5.107 & Outer Pipe for LLW System & $x$ & (4) & & $x$ \\
\hline Subsection 5.128 & $\begin{array}{l}\text { Stainless-Steel Systems - High } \\
\text { Quality (Inner Pipe) }\end{array}$ & $x$ & $x$ & $x$ & $x$ \\
\hline Subsection 5.147 & $\begin{array}{l}\text { Hastelloy -C Piping Systems } \\
\text { (Inner Pipe) }\end{array}$ & $x$ & $x$ & $x$ & $x$ \\
\hline \multicolumn{2}{|c|}{ Field Welds for Subsections $5.128 \& 5.147$} & $x$ & $x$ & $x$ & $x$ \\
\hline
\end{tabular}

NOTES: (1) Visual inspection to be in accordance with MMES Procedure W-50A.

(2) Radiographic examination to be in accordance with MMES Procedure W-52.

(3) Dye Penetrant Examination to be in accordance with MMES Procedure W-51.

(4) Random (up to $5 \%$ ). 
IV.B.4. Backfilling

- MCS:

Backfill around the reinforced concrete tank vault will be stabilized aggregate base course. This will consist of a premixed base material of crushed stone, binder material, and water, meeting the requirements of the Tennessee Department of Transportation "Standard Specifications for Road and Bridge Construction." Backfill will be placed in horizontal layers of 6-inch thickness, maximum, and compacted to a minimum of $92 \%$ of the maximum dry density and within $2 \%$ of the optimum moisture content as determined per AASHTO T-180. The required compaction and moisture content will be verified during fill placement by means of in-place density tests per AASHTO T-191, T-205, or T-238.

Due to its dense and primarily granular nature, the backfill will have a friction angle of at least $40^{\circ}$, with some cohesion (ignored for design), rendering it unsusceptible to liquefaction during an earthquake. Also, while providing excellent compactability during construction, the backfill will minimize lateral pressure on the tank vault walls, compared to a backfill consisting of excavated soil. This assessment concludes that the design and specification of the backfill will ensure that the tank vault structure will be fully and uniformly supported. The installation of the backfill will be inspected to verify conformance with the project specifications.

- LLW Underground Piping:

Bedding and backfill material immediately surrounding all new pipe will be a uniform mixture of sand and $4 \%$ bentonite. The sand/bentonite mixture will flow freely and compact well during installation, under controlled moisture conditions. These properties facilitate the provision of a uniform bedding and backfill 
REQUIRED INSPECTION REPORTS

INSPECTION REPORT

Piping Welds

Visual Inspection

100\% Radiography

Dye Penetrants, First and Last Pass
SPEC. REFERENCE

5.100, Attachment 1

5.100, Attachment 1

5.100, Attachment 1

5.107, Paragraph 2.E

5.128, Paragraph 2.E.2)

5.147, Paragraph 2.E.2)

5.128, Paragraph 2.E.3)

5.147, Paragraph 2.E.3)

\section{LLW Tank}

Radiography of Welds

Longitudinal and Circumferential Butt Welds

9.101, Paragraph 9.A.a

Dye Penetrant Exam of Welds

Nozzle to Shell, Nozzle to Head Welds

9.101, Paragraph 9.A.6

Welds of Appurtenances, Lifting Lugs, Supports to Tank Shell

9.101, Paragraph 9.A.C

Vault Liner Welds

Visual Inspection

4.740, Paragraph 8A

Dye Penetrant, Last Pass

4.740, Paragraph 8B 
for the buried piping, with desirable physical properties. Due to its swelling capability, the bentonite makes the mixture less permeable to moisture than sand.

The sand will have a maximum moisture content of $10 \%$ just prior to mixing, as determined per AASHTO T-255, and will be a silicious sand produced from crushed sandstone. The maximum levels of leachable chlorides and sulfates will be as follows, as determined by the Government per USDOE's "Determination of Inorganic Anions in Aqueous and Solid Samples by lon Chromatography" test method:

Sand

Chlorides

Sulfates
$10 \mathrm{ppm}$

$100 \mathrm{ppm}$

\section{Bentonite}

$50 \mathrm{ppm}$

5000 ppm

These limits are established by USDOE to reduce the potential for pipe corrosion. They are based on past experience with other backfills surrounding existing similar piping at the site.

The sand/bentonite mixture will be carefully compacted to $91 \pm 1 \%$ of the maximum dry density, per AASHTO T-180, in layers not exceeding 6 inches in thickness. In-place density and moisture content tests will be performed per AASHTO T-191,T-204, T-205. $T-233$, or $T-238$.

This assessment concludes that the design and specification of the backfill will ensure that the buried piping will be fully and uniformly supported. The installation of the backfill will be inspected to verify conformance with the project specifications. 
IV.B.5. Testing

The pressure containing boundary of the primary and secondary piping and the LLW tank is tested for leak tightness prior to being covered, backfilled, enclosed, or placed in service. The leak tests are either pneumatic or hydrostatic tests, conducted in accordance with applicable MMES specifications. These test requirements are noted in the Installation Assessment Summary and are summarized below:

\section{Leak Testing Requirements}

\begin{tabular}{|c|c|c|c|}
\hline System/Component & Type of Test/Media & Code & Spec Reference \\
\hline Primary Pipe & Pneumatic/Nitrogen & $\mathrm{B} 31.3$ & 5.410, Table 1 \\
\hline Secondary Pipe & Pneumatic/Nitrogen & B31.3 & 5.410, Table 1 \\
\hline LLW Tank & Hydrostatic & ASME VIII & 9.101, Para 9.b.3) \\
\hline
\end{tabular}

These test reports will be reviewed by the installation Assessment Team to assure that leak-tight construction has been provided.

\section{IV.B.6. Ancillary Equipment Protection}

The methods implemented to properly support and protect ancillary equipment against physical damage and excessive stress due to settlement, vibration, expansion, or contraction are described herein. The methods used may be divided into three categories as applicable to buried double wall piping systems; single wall piping systems within a lined, seismically designed structure; and an LLW tank (single wall) within a lined, seismically designed structure.

The buried double wall piping is completely surrounded by a sandbentonite mixture, with at least 3 feet of cover. The sand-bentonite mixture fills the bottom of the trench in which the piping system is routed. The relatively low moisture permeability of the mixture prevents the sand from acting as a conduit or wick to transport 
potential leakage significant distances, in the presence of groundwater. The remainder of the trench backfill consists of either a premixed base material of crushed stone or earth.

The piping system has been analyzed for the various loading conditions that may apply, including: (1) potential settlement of structures at which the piping system terminates or is anchored; (2) seismic loadings induced by the design basis seismic event; (3) thermal expansion caused by upset operation, with live steam in the primary pipe (potentially caused by operation of a steam jet ejector with suction from a dry tank or sump). The stresses induced in the piping system (primary and secondary pipe) are within ANSI B31.3 code allowable values for the applied loadings.

The single wall LLW piping routed within a lined structure is supported for dead weight. Where appropriate, additional restraints are provided for lateral forces that may be induced by hydraulic conditions. Seismic restraint is not required since the piping is contained within a lined, seismically qualified Secondary Containment structure equipped with a leak detection system. It should be noted that the basic design inherently provides a significant degree of seismic event resistance since most runs of piping in this category are relatively short and stiff. Also, the seismic accelerations are modest because the vault structures are below grade and are themselves relatively rigid. (Amplification of seismic inputs due to structural response is minimal.)

The LLW tank is welded to support saddles, which in turn, are attached to the floor slab of the underground vault. The LLW tank specification requires that the tank and its supports be designed to withstand specified seismic loadings. The anchor bolts and floor slab are designed to withstand uplift and pullout forces caused by seismic loadings. 
This assessment concludes that the design has incorporated adequate provisions for the protection of ancillary equipment against physical damage and excessive stress. The installation will be assessed in accordance with the requirements presented in the Installation Assessment Summary, Section IV.B.2 of this report.

\section{IV.B.7. Corrosion Protection}

A thorough review of the pertinent drawings and specificationswas performed to ensure that all corrosion protection recommendations were incorporated. In addition, all review comments were analyzed to determine if they had been adequately considered. The results of this review found that with the exception of a few minor discrepancies, which have been corrected, all comments and design recommendations have been properly incorporated.

There are a number of procedures that are required to verify whether the cathodic protection system has been properly installed and tested. This is primarily accomplished by measuring pipe to soil potentials. This work is performed by a qualified corrosion engineer per N.A.C.E. recommended practice 01-69, Rev. 1983, as noted in Section IV.B-2, Installation Assessment Summary.

This assessment concludes that the design incorporates an appropriate type and degree of corrosion protection for the buried piping. The installation of the corrosion protection systemmust be supervised by an independent corrosion expert who will, upon completion of the installation, provide a certification that the installation complies with the design requirements. The certification will be audited by the installation inspector as part of the installation assessment. 


\section{IV.B.8 Corrosion Expert}

Norton Corrosion Limited, Inc., a firm that specializes in corrosion control, was involved in the design phase of the subject project.

This work was assessed by an outside firm hired by Martin Marietta that reviewed the design calculations and provided comments. All comments were reviewed and appropriate changes made.

Guidance to ensure the results will be implemented are found in the specifications. These require that the contractor hire a N.A.C.E. certified corrosion engineer to inspect and test the corrosion control system. It also requires submittal of all materials and qualifications for review prior to installation.

\section{IV.B.9 Documentation}

This section contains written statements by those persons required to certify the design of the Tank System and supervise the installation of the Tank System. Separate statements are provided, one covering the design of the Tank System, the other covering the installation of the Tank System (Exhibits B.9-1 and B.9-2).

The installation certification will be signed and stamped following the completion of the installation and a review of pertinent records documenting required non-destructive examinations, inspections, repairs, and tests. These activities are described in Sections IV.B.2 through and including IV.B.7 of this assessment.

Suitable retrievable permanent records of the results of the aforementioned non-destructive examinations, inspections, repairs, and tests will be maintained by the Information Services Division of Martin Marietta Energy Systems. These records will be reviewed by the person who will, in the future, certify the installation. 


\section{Exhibit B.9-1}

\section{DESIGN CERTIFICATION}

This statement certifies that the replacement Tank System providing Low Level Waste collection, storage, $\mathrm{pH}$ adjustment, and transfer for the High Radiation Analytical Laboratory (Building 2026) and its Monitoring and Control Station (Building 2099) is properly designed, and the design is in accordance with the applicable requirements of 40CFR264, Subpart J -Tank Systems, as set forth in Appendix $F$ to the Federal Facility Agreement, Docket No. 89-04-FF, covering the Oak Ridge Reservation.

This statement applies to the design of the Tank System and to the provisions specified by the design (examinations, inspections, tests) that must be executed during installation, including the conduct of any repairs that may be required during installation. A separate statement must be prepared and certified, following the installation of the Tank System, to attest that the final installation is in compliance with the design and with provisions of 40CFR264, Subpart J - Tank Systems, as presented in Appendix $F$ to the Federal Facility Agreement, Docket No. 89-04-FF.

1, the undersigned, certify that this document was prepared under my direction by qualified personnel who had complete access to pertinent design information. Based on my inquiry of those persons directly responsible for gathering and evaluating the information, the information submitted is, to the best of my knowledge and belief, true, accurate, and complete.
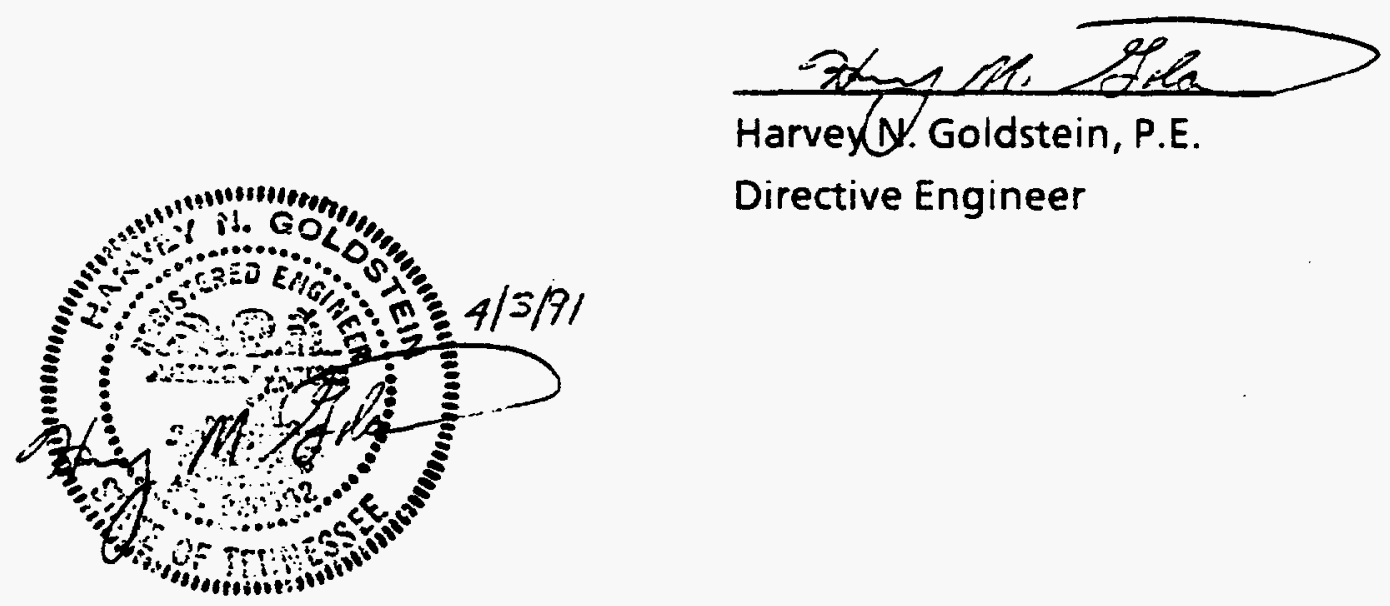

No. 020602 
Reserved for Exhibit B.9-2 - Installation Certification

(Please note format used for Design Certification) 


\section{IV.C. Standards for Containment/Release Detection}

The secondary containment systems consist of an outer pipe completely enveloping the primary, inner pipe and a lined, seismically designed, reinforced concrete vault containing the LLW tank.

The release detection system for the piping system utilizes nitrogen pressure maintained in the annular space between the inner and outer pipes, with continuous pressure monitoring. The release detection system for the tank system utilizes a sump at a low point in the liner/vault structure, with a level probe set in the sump to detect the presence of more than a de minimus amount of liquid.

\section{IV.C.1. Secondary Containment Systems Requirements}

(a) Construction Compatibility:

The secondary containment for the piping system is constructed of Type 304L austenitic stainless steel. This material is capable of withstanding limited, short term exposure to substances that may potentially leak from the service lines connecting Building 2026 (source) to Building 2099 (MCS). The waste substances principally drain by gravity, in small quantities, to the waste tank in the MCS. A leak will be detected within a short time interval, which will result in an orderly cessation of waste disposal via the affected service line. The small quantity of liquid leaked from primary to secondary piping will be contained until draining and flushing actions commence.

The Type 304L stainless steel secondary pipe is fully capable of containing substances that may potentially leak from the primary transfer line from the MCS to existing valve box No. 1A. The waste substances that are transferred via this line will have been neutralized ( $\mathrm{pH}$ adjusted from highly acidic to nearly neutral) and will be much less aggressive chemically 
than untreated waste. The flanged connections in the LLW piping, which terminate the cathodic protection for the buried portions of the system, are located within a stainless steel lined, reinforced concrete junction box immediately external to Building 2026.

The secondary containment surface material for the LLW tank (i.e., the vault liner), which could be exposed to LLW, assuming leakage through the primary containment, is in all cases Type. $304 \mathrm{~L}$ stainless steel material. The secondary containment is, therefore, compatible with the LLW waste streams or other substances placed in the LLW Tank System.

The reinforced concrete tank vault walls, base slab, and cover slabs have been conservatively designed for appropriate loadings including pressures due to surcharge, seismic, earth, and hydrostatic loadings. For purposes of design, ground water level was assumed to be at grade level. The cover slabs have been designed for a minimum of 300 psf live load and have also been checked for postulated tornado missile loads associated with high hazard classification in accordance with UCRL-15910. The tornado load calculation included postulated collapse of the adjacent control room and shield walls surrounding the HVAC equipment area, onto the vault roof slab.

Other tornado design basis loads that were evaluated include wind pressure, atmosphere pressure change, and missiles, including a wood plank, a steel pipe, and a medium sized automobile.

The relatively thick cover slabs provided for radiation shielding (24 inches over the valve vault 36 inches over the tank vault, and 18 inches over the junction box) are conservatively adequate for all design loads. The concrete mix design incorporates entrained air to assure durable concrete 
with no deterioration due to freeze/thaw cycles anticipated over the service life of the vault.

Applicable American Concrete Institute Standards such as ACI 305, "Hot Weather Concreting," and ACl 306, "Cold Weather Concreting," assure the necessary quality of concrete will be achieved under a potential range of climatic conditions during construction. In addition to the many quality requirements embodied in $\mathrm{ACl} 318$ and $\mathrm{ACl} 301$, which are specified, water content and the addition of water to the concrete are carefully controlled to minimize drying shrinkage.

Various in-process tests, including cylinder compressive strength tests, have been required to assure consistency in the concrete mix being furnished.

New LLW pipes located beneath the grade floor level within Building 2026 are provided with at least the equivalent of 18 inches of concrete cover for shielding. The cover protects the piping from any damage due to vehicular wheel loads including the wheel loads along the tracks for the removable cell plugs at the back of the cells.

These double wall pipes are fully encased in concrete. Mild steel reinforcing is distributed within the concrete encasement to limit the width of any shrinkage cracks assuring against local overstress of the encased LLW piping.

\section{(b) Containment Systems Foundation}

The secondary containment system foundation consists of the 2 -foot thick reinforced concrete vault base slabs.

The MCS vaults consisting of the tank vault, valve vault, and mist eliminator vault are integrated into a single rigid 
reinforced concrete structure. This structure is founded on rock and is embedded below grade.

Due to the rigid nature of the structure and the foundation bearing on rock, the potential for bearing failure and/or settlement are negligible. The vault structure stability has been checked to assure that the dead weight of the structures conservatively exceeds an assumed buoyancy force due to groundwater level assumed to be at grade.

The vault base slab has been conservatively designed assuming a rigid slab model for an upward pressure corresponding to the dead plus live load of the superstructure divided by the area of the slab.

The vault walls have been designed for applicable lateral loads due to surcharge, static earth pressure, hydrostatic head of water, and lateral pressure increment due to a seismic event.

This assessment concludes that the containment systems foundation has the capability to provide support to the secondary containment system without failure and is designed for the appropriate loading conditions.

\section{(c) Leak Detection System}

The secondary containment system's leak detection provisions are divided into two approaches:

(i) Double Wall Piping Annulus Leak Detection

The annular spaces in the double wall piping systems are pressurized with nitrogen. The piping runs are divided in multiple segments, each constituting an independent pressure boundary, by division plates in the piping system. 
The system configuration inside Building 2026 for double wall piping embedded within floor slabs divides the piping into segments. Each segment represents a branch or run comprising part of the system and is pressurized with nitrogen at $15 \mathrm{psig}$. A pressure switch is provided for each segment, which opens a contact upon decreasing pressure, actuating an alarm. The loss of nitrogen pressure from the annular spaces provides an indication of a leak in either the primary pipe, the secondary pipe, or the nitrogen pressurization/sensing line itself. The localization of the leak is facilitated by the segmentation noted above.

The system configuration, for the buried double wall service lines conveying LLW from Building 2026 to Building 2099 (MCS), and transfer lines from Building 2099 to valve box No. 1A, divides each run of pipe into segments with test and monitoring stations provided at the junction between segments. Pressure monitoring for each line utilizes two pressure switches ( 1 out of 2 logic) serving all the buried pipe segments. If a potential leak is detected, by decrease of annular space pressure, the leak location may be determined by acoustic monitoring or by entering the test and monitoring station and sequentially isolating segments of the buried line.

The assessment concludes that the aforementioned leak detection system for the annular space of the double wall piping system is capable of detecting virtually all leaks within considerably less than 24 hours. 


\section{(ii) Tank Leak Detection System}

The detection of leaks from the LLW tank in the MCS is based on the provision of a sump at the low point in the sloping tank vault floor. Any leakage from the tank would flow by gravity to the sump, which is provided with a conductivity type level detection device. The time period required for this accumulation of liquid will vary inversely with the rate of a potential leak (i.e., the larger the leak, the shorter will be the time interval required to detect the leak).

The total quantity of a non-detected leak represents a very small fraction of the minimum rated tank capacity ( 1100 gallons), and is contained by the sump liner, which is a continuous part of the vault liner. The assessment concludes, therefore, that extremely small leaks, even if not detected within 24 hours, will be detected at the earliest practical time.

\section{(d) Drainage and Liquid Removal}

The secondary containment systems are designed to permit removal of accumulated liquids arising from leaks, spills, or condensation within the secondary containment volumetric envelope.

(i) Double Wall Piping Annulus Liquid Removal

Each individual segment of each run of double wall piping is sloped to a low point at one of its ends. A drain nipple is provided at the low point, with connecting tubing routed to a connecting point from which accumulations of liquids arising from potential leaks may be removed. The annular space drain points are accessible from 
numerous test and monitoring stations provided at each pipeline segment junction. Leaked substances may be removed in the length of time required to detect a leak and gain access to the test and monitoring station, which consists of a standard concrete pipe section installed vertically with a weatherproof cover. Additional connections are provided to the annular space for venting and/or injection of a flushing liquid, if required.

The as-built plan and profile of the buried piping will be reviewed during the installation assessment to assure that the design provisions for liquid removal capability are not compromised. Deviations in plan and profile during construction of the buried pipelines must have engineering approval prior to final placement of the piping.

(ii) LLW Tank Liquid Removal

The tank vault containing the LLW tank is provided with a sloped floor and a sump of approximately 14 gallons net capacity. The sump is provided with two steam jet ejectors that can pump any accumulated liquid back to the tank or to the LLW transfer line for conveyance to the $\mathrm{CWCH}$ at valve box $1 \mathrm{~A}$. The steam jet ejectors can operate to remove liquids within minutes of a decision to do so.

\section{(iii) Single Wall Piping Liquid Removal}

The single wall LLW piping within the confines of the MCS valve and tank vaults are provided with 
secondary containment by the stainless steel liners of each vault. Leaking liquids are captured by the sumps provided and removed by means of steam jet ejectors. The valve vault is provided with a single steam jet ejector, which is piped to convey any accumulated liquid from the valve vault sump to the LLW tank. The tank vault sump is provided with two ejectors; as discussed in (d)(ii) above.

\section{(e) Secondary Containment for Tanks}

The secondary containment system for the LLW tank consists of a stainless steel liner external to the tank. The liner is continuously welded so that it forms a leaktight containment system for liquids. The liner is attached to the inner surface of a reinforced concrete vault. The vault structure is designed to withstand specific, defined loading conditions, as described in paragraph IV.B.1.(e) of this assessment.

The Building 2099 LLW tank, therefore, is provided with two specific features, integrated into a secondary containment system, which provide a high degree of environmental protection against leaks or spills from the primary containment vessel.

\section{(f) Additional Requirements}

(i) External Liner Systems

The design of this Tank System does not utilize an external liner to achieve compliance with 40CFR264 Subpart $\mathrm{J}$ requirements. However, an external water proofing membrane is provided on the outside of the 
vault structures described below. The function of this membrane is discussed in (ii)(D).

(ii) Vault Systems

\section{(A) Capacity}

The Building 2099 tank vault is provided with a leak-tight stainless steel liner, from and including the floor of the vault, up to a height of $4 \mathrm{ft}$. -6 in. (nominal) above the floor. This provides a gross volume of approximately 7,500 gallons, compared to the LLW tank volume, at overflow, of approximately 2,000 gallons. The lined vault system, therefore, provides a margin of safety in capacity of several times the volume of the LLW tank contained within the vault.

\section{(B) Run-on or Infiltration Prevention}

Surface water drainage will be directed around the MCS building by means of site grading. Storm drain catch basin inlets, as well as existing site topographic relief, will prevent the build-up of surface water during storm/rainfall events. Site grades immediately surrounding the MCS are maintained at lower elevations than the MCS perimeter walls.

The design of the surface water drainage is combined with the characteristics of the vault subsurface design to prevent surface run-off from entering the vault. The presence of existing site fine-grained soils, combined with the dense tank vault backfill materials and the proposed grass ground cover, will minimize surface water infiltration as a result of precipitation. The 
reinforced concrete tank vault walls and the external waterproofing membrane also will protect the tank from run-on and infiltration effects.

The vault system has been provided with redundant design features to prevent run-on or infiltration of precipitation into the secondary containment system. The cover slabs are provided with drainage pitch to channel water off the top surface of the vault and into the surface run-off drainage system. The opening into the tank vault for installation (or removal) of the tank is provided with a two-piece cover slab arrangement that provides redundancy against infiltration at the openings. Each of the two pieces completely covers the opening in the stacked arrangement. Each slab is also furnished with a continuous flexible gasket under the perimeter that is compressed to provide a seal. The top cover slab extends horizontally over a continuous curb provided around the perimeter of the opening. This cover slab arrangement provides redundancy against infiltration and also places no flexible seals in a potential direct leakage path into the vault through use of the concrete curb.

The reinforced concrete vault structure meets applicable requirements of $A C I 350 R$ for concrete sanitary engineering structures, including reinforcing ratios and bar spacing as well as concrete quality. 
Six-inch flexible polyvinyl chloride waterstops are provided in all construction joints below grade. This material is chemically resistant.

\section{(2) Coating or Lining}

The interior of the concrete vaults is provided with an impermeable coating and lining that is compatible with the stored waste and will prevent the migration of waste into the concrete. A continuous stainless steel liner is fastened to the interior surface of the vault base slab and walls. This liner provides the leak-tight barrier to contain more than $100 \%$ of the tank volume (see Paragraph IV.C.1.(f)(ii)(A). The remainder of the interior surfaces of the tank vaults above the stainless steel liners are coated with an impermeable epoxy coating system that will prevent migration of any liquid through it into the concrete.

\section{(C) Vapor Protection}

The vault systems are provided with the means to protect against the formation and ignition of vapors within the LLW tank and within the valve and tank vaults. These provisions are comprised of multiple design features, as described below. The LLW tank is the only potential source of ignitable waste since wastes are normally contained only in the tank and not in the vaults. Ignitable waste may evolve in the LLW tank in the 
form of the gaseous phase of any of several organic liquids such as acetone, benzene, methanol, or ethanol. These liquids may be used, in small quantities, in the operations of Building 2026 and, hence, may be discharged to the LLW tank.

A study by ORNL personnel (Ref. Appendix $G$ of the System Requirements Document for the Bethel Valley LLW Project) examined the potential for ignitable vapor formation within the LLW tank and evaluated ventilation rates that would maintain concentrations of the ignitable vapors below the flammability limit.

The principal means of protection against the formation and ignition of vapors within the LLW tank is the provision of direct ventilation of the gas space above the liquid level in the tank. The ventilation rate is set at $100 \mathrm{cfm}$, which is well in excess of flow rates established in Appendix $G$ of the Bethel Valley LLW System Requirements Document.

The ventilation rates for the valve and tank vaults are set at $240 \mathrm{cfm}$ by space heating and normal ventilation criteria. Since no identified mechanism exists for vapor formation in the vaults, the aforementioned ventilation rate should be more than adequate to maintain the vaults free of any potential for vapor formation and ignition.

A second design provision that provides detection of vapors is combustible gas detection instrumentation. A combustible gas monitor 
sensor is located in the ventilation air exhaust from the LLW storage tank (Building 2099), downstream of the mist eliminator. This sensor is flange mounted into the exhaust duct to allow ease of removal for calibration. The sensor is a catalytic bead diffusion type operating on 24 VDC supplied by readout module in the control room panel. The readout provides a display range of 0-99\% Lower Explosive Limit with an alarm output set at $50 \%$ or less to the Local Control Unit (LCU). Alarm is also provided on loss of power, or unit malfunction.

A third design provision that provides protection against the formation and ignition of vapors is a nitrogen flooding system that enables the operator to purge the vapor space of the LLW tank and establish a nitrogen blanket above the liquid in the tank. The ventilation to the tank would be terminated prior to establishing the nitrogen blanket, which can be maintained until operational decisions are made for handling the situation.

Another design feature that assists in the protection against the ignition of vapors within the tank includes the specification of an explosion-proof type duct heater in the duct exhausting from the LLW tank, through the mist eliminator, and to the first exhaust HEPA filter. A duct heater is required to reduce the relative humidity of the air stream to the HEPA filter; the explosion-proof rating reduces or eliminates the 
potential for ignition of any flammable vapors that may be present.

Finally, the LLW tank is grounded, minimizing the potential for the build-up of a static charge, with subsequent discharge of a spark or arc which could ignite any flammable vapors that may be present.

(D) Moisture Migration

The reinforced concrete vault structure has been conservatively designed for hydraulic pressure from groundwater level assumed to be at grade. While ground water levels are normally well below grade, an impervious, continuous, single layer elastomeric waterproofing membrane has been provided.

The waterproofing membrane completely envelopes the exterior surfaces of the vault, including under the base slab and along the walls up to a level approximately 6 inches below finished grade. Finished grade around the vault is sloped to channel surface run-off away from the vault.

It is concluded that the provision of the external membrane waterproofing system will prevent migration of moisture into the vaults. 
(iii) Double Walled Tanks - Not Applicable

(iv) Support Equipment

Support equipment is provided with secondary containment that meets the requirements stated previously in this section (IV.C.) except for limited portions of aboveground piping that are visible for inspection on a daily basis. These piping segments are located in specific areas within Building 2026, principally in the laboratory area. Other items of support equipment and their secondary containment features are noted below.

- Buried or embedded piping is provided with double wall construction, the outer pipe constituting the secondary boundary. Leak detection and a means of removal of accumulated leakage are provided for the annular spaces between the primary and secondary pipes.

- Steam jet ejectors are used to remove spills or leaks of accumulated liquid waste from the scrubber pits and the instrument pit in Building 2026. The scrubber and instrument pits represent the secondary containment for the scrubber vessels, pumps, and piping. Level detection instrumentation is provided for the sumps or low points in the pit areas.

- Steam jet ejectors, used to pump liquid waste from the LLW tank and vault sumps, are housed below grade within the lined secondary containment vaults. 
- Portions of the LLW tank ventilation equipment that may contain liquid waste (principally the mist eliminator and associated piping) are located within a lined vault, adjacent to and structurally integral with the LLW tank vault. The floor of the mist eliminator vault is equipped with a floor drain that is piped to the LLW tank. The embedded portion of the mist eliminator vault floor drain piping is provided with an outer, secondary pipe.

This outer pipe is seal welded to the mist eliminator vault floor liner, but is open as it enters the LLW tank vault. Potential leakage from the inner pipe would be contained by the outer pipe and would flow by gravity to the tank vault sump where it would be detected by the sump level detection instruments.

It should be noted, however, that if the mist eliminator vessel, or its connecting pipe or flanges were to leak, this leak could not be directly detected. Any leakage would be conveyed to the LLW tank via the mist eliminator vault floor drain. The leakage could not accumulate, but instead is directly returned to the primary containment vessel (i.e., the LLW tank). This condition was observed during the assessment review process; a design change to reroute the mist eliminator vault floor drain to the tank vault sump will be implemented. This will provide the capability to detect potential leaks from the mist eliminator vessel and its connecting piping and flanges.

- The HEPA filter housings, comprising part of the tank ventilation system, are located above grade and are accessible for daily inspection. The 
housings are equipped with valved closed drain connections, which may be manually drained on a periodic basis.

- Flanged connections used to terminate cathodic protection circuits are located in stainless steel lined vaults (also termed "Junction boxes") and equipped with sumps and level detection instrumentation. The cover slabs of these vaults are equipped with a pipe sleeve and removable pipe cap, which permits the entry of tubing to remove any accumulated liquid. A small sample may be removed for analysis prior to removal of the entire sump contents.

- Flanged connections used for tie-ins of transfer lines to the $\mathrm{CWCH}$ are located in existing valve box No. 1A. The valve box is provided with a stainless steel liner and a sump (the liner is continuous and includes the sump), and an access port in the box cover slab. The access port permits sampling and removal of accumulated liquids. A leak detection system has not been provided as part of the scope of work for the Bethel Valley LLW Upgrade, which was limited to new valve boxes only. The Bethel Valley LLW Upgrade scope at existing valve boxes only included modifications to the piping and box structure to permit tie-in to the CWCH. The provision of a leak detection system for existing valve boxes should be considered in future LLW upgrades.

- The design of this facility does not employ sealless or magnetic coupling pumps and sealless valves that require inspection on a daily basis. 
- The design of this facility does not employ pressurized aboveground piping systems with automatic shut-off devices for the liquid waste.

In summary, this assessment concludes that support equipment is provided with acceptable secondary containment provisions, including leak detection and means for removal of accumulated liquids, as applicable. 


\section{v. CONCLUSION}

This assessment concludes that the completed design for the new Tank System for the Building 2026/2099 complex meets the applicable requirements of 40CFR264 Subpart J-Tank Systems, as presented in Appendix $F$ to the Federal Facility Agreement, Docket No. 89-04-FF.

- The waste tank and primary (inner) piping are specified to the appropriate codes and with the appropriate materials to provide satisfactory longevity in the intended service. The specifications require appropriate materials properties, weld examination and inspection, testing, and final visual inspections to assure leak tight integrity.

- Secondary containment features are provided where required for the waste tank and buried or embedded piping. Leak detection and means of removing accumulated liquids are provided within the scope of the design. The vault structures have been designed for the applicable loadings and load combinations for high hazard category structures, in accordance with UCRL 15910, including loadings associated with postulated seismic and tornado occurrences. A stainless steel liner has been provided in the vaults as the secondary containment barrier. Appropriate materials, fabrication and installation techniques, examinations and inspections have been specified to assure that the required quality and integrity of the design is achieved during construction.

- The buried piping is provided with a corrosion control system that projects a useful life span well in excess of the planned operational life of the system ( 125 years versus 25 years). Overall the corrosion control designs offer a very conservative approach and meet all criteria listed. The main concern with any cathodic protection system, but especially a galvanic system, is to maintain electrical isolation from all foreign structures. This has been accomplished throughout the design phase and is incorporated in the testing procedures to assure that isolation is maintained following installation. 
- The civil and geotechnical engineering design provides a satisfactory approach to the overall integrity of the Tank System and is based upon site, subsurface, and pipe backfill data provided by the Government to the Architect/Engineer. Project construction drawings and technical specifications provide requirements, tests, and approvals necessary to assure a successful installation.

- Support equipment is protected against physical damage and excessive stress due to vibration, settlement, and expansion or contraction. Secondary containment is provided for ancillary equipment, meeting the same standards as for the waste tank. One exception was noted during the assessment review (the mist eliminator; Section IV.C.1.(f) (iv)). A minor design change will be implemented to provide complete conformance to leak detection requirements. In addition, it is noted that provision of leak detection for existing valve box No. 1A was not within the scope of work for the Bethel Valley LLW Upgrade. Future upgrades should consider provision of leak detection for this and other valve boxes, as may be required.

The installation assessment, to be performed during installation and prior to commissioning of the system, is to confirm that design provisions have been correctly implemented: The Installation Assessment Team will review pertinent test and inspection records, and perform visual inspections, walkdowns, and witness functional tests to achieve this objective. An installation certification is to be prepared and inserted in Section IV.B. 9 of this document. 
Appendix

\section{LISTINGS OF DRAWINGS AND DOCUMENTS}




\section{DRAWING INDEX}

A. WBS 1.1 - External Piping

1. WBS. 1.1.1 - High Radiation Level Analytical Laboratory - Building 2026

Drawing

Number

C3E-20013-A078

C3E-20013-A057

C3E-20013-A058

C3E-20013-A059

C3E-20013-A060

C3E-20013-A061

C3E-20013-A064

C3E-20013-A066

E3E-20013-D038

E3E-20013-D039

E3E-20169-D041

E3E-21359-D003

E3E-21359-D004

PE3-20013-C200

PE3-20013-C201

P3E-20013-C202

P3E-20013-C203

P3E-20013-C204

P3E-20013-C205

S3E-20013-BOO4

I3E-21359-0034

I3E-21359-0035

I3E-21359-0037
Revision

0

0

$\mathbf{0}$

0

0

0

0

o

Electrical-Cathodic Protection Layout - Transfer \& Service Line Piping Electrical-Cathodic Protection Layout - Sections and Details

Conduit Layout Plan-First Floor

Conduit Layout-Plans

Conduit \& Cable Tray Layout-Plan, Sections \& Details

\section{MECHANICAL}

External Piping for HRLAL - Piping System-Service Lines Details Sheet 1 External Piping for HRIAL - Piping System-Service Lines Details Sheet 2 External Piping for HRLAL - Piping System-Service Lines Details Sheet 3 External Piping for HRLAL - Piping System-Transfer Line Detail Sheet 1 External Piping for HRLAL - Piping System-Transfer Line Detail Sheet 2 External Piping for HRLAL - Piping System-Transfer Line Detail Sheet 3

\section{STRUCTURAL}

External Piping for HRIAI - Junction Boxes 2026-1 \& 2026-2, Plan and Sections

$\underline{I \& C}$

Monitoring \& Control Station for HRLAL, Loop diagram Valve Loop Diagram Valve Box Leak Detection LE-9915, 9916

Monitoring \& Control Station for HRLAL, connection Diagram Valve Box 1A

Installation Details, Panel K9910 
B. WBS 13.1 - MONITORING AND CONTROL STATION FOR HRLAI - BUILDING 2099

\begin{tabular}{|c|c|c|}
\hline $\begin{array}{l}\text { Drawing } \\
\text { Number }\end{array}$ & Revision & Title \\
\hline & & Architectural \\
\hline A3E-21359-B008 & 0 & Plan, Section \& Detail \\
\hline A3E-21359-B009 & 0 & Exterior Elevations \\
\hline A3E-21359-B010 & 0 & Sections \& Details \\
\hline A3E-21359-B011 & $\mathbf{0}$ & Roof Plan and Sections and Details \\
\hline A3E-21359-B012 & 0 & References and Schedules \\
\hline A3E-21359-BO13 & 0 & Building \& Equipment Arrangement-Plan at Grade and Below \\
\hline \multirow[t]{2}{*}{ A3E-21359-B014 } & $\mathbf{0}$ & Building \& Equipment Arrangement Section, A-A \& B-B \\
\hline & & Electrical \\
\hline E3E-21359-D001 & 0 & One Line Diagram DP1-5A 480V Motor Center \\
\hline E3E-21359-D002 & $\mathbf{0}$ & Elementary \& Wiring Diagrams Heat Trace, HVAC \& Misc. Systems \\
\hline E3E-21359-D003 & $\mathbf{0}$ & Conduit Layout Plans \& Details \\
\hline E3E-21359-D004 & $\mathbf{0}$ & Conduit \& Cable Tray Layout-Plan, Sections \& Details \\
\hline E3E-21359.D005 & $\mathbf{0}$ & Conduit Layout- Plan-Overhead Lines \\
\hline E3E-21359-D006 & $\mathbf{0}$ & Grounding Layout Plans, Sections, Details \& Legend \\
\hline E3E-21359-D007 & $\mathbf{0}$ & Lighting Layout - Plans, Sections, Notes, \& Legend \\
\hline E3E-21359-D008 & 0 & Electrical Cable List \\
\hline E3E-21359-D009 & $\mathbf{0}$ & Electrical Cable List \\
\hline E3E-21359-D010 & $\mathbf{0}$ & Electrical Cable List \\
\hline \multirow[t]{2}{*}{ E3E-21359-D020 } & $\mathbf{0}$ & Electrical Cable List \\
\hline & & Piping \\
\hline P3E-21359-C001 & $\mathbf{0}$ & Fuid System Diagram- Steam Distribution System \\
\hline P3E-21359-COO2 & $\mathbf{0}$ & Fluid System Diagram - Caustic System \\
\hline P3E-21359-COO3 & $\mathbf{0}$ & Fluid System Diagram - Compressed, Air Distribution System, \\
\hline P3E-21359-0004 & $\mathbf{0}$ & Fluid System Diagram - Low Level Waste System \\
\hline P3E-21359-CO05 & $\mathbf{0}$ & Fluid System - Potable/Process Water \\
\hline P3E-21359-CO06 & $\mathbf{0}$ & Piping System - Plan Above Elevation $856^{\circ}-6^{\prime \prime}$ \\
\hline P3E-21359-0007 & $\mathbf{0}$ & Piping System - Plan Below Elevation 856 -6" \\
\hline P3E-21359-CO08 & $\mathbf{0}$ & Piping System - Valve Pit \& Tank Vault-Sections \\
\hline P3E-21359-0009 & $\mathbf{0}$ & Piping System - Valve Pit - Sections \& Details \\
\hline P3E-21359-CO10 & $\mathbf{0}$ & Piping System - Sections Above Elevation 856'-6, Sheet 1 \\
\hline P3E-21359-CO11 & $\mathbf{0}$ & Piping System - Sections Above Elevation $856^{\prime}-6^{\prime \prime}$, Sheet 2 \\
\hline P3E-21359-CO12 & $\mathbf{0}$ & Piping System - Sections \& Details \\
\hline P3E-21359-CO13 & $\mathbf{0}$ & Piping - Details \\
\hline P3E-21359-CO14 & $\mathbf{0}$ & Floor \& Equipment Drains \\
\hline
\end{tabular}


WBS 1.3.1 - MONITORING AND CONTROL STATION FOR HRLAL - BUILDING 2099 continued

\section{Drawing \\ Number}

P3E-21359-C015

P3E-21359-C016

P3E-21359-C017

S3E-21359-B001

S3E-21359-B002

S3E-21359-BO03

S3E-21359-BO04

S3E-21359-BO05

S3E-21359-B006

S3E-21359-B007

S3E-21359-B015

S3E-21359-B016

C3E-21359-A001

C3E-21359-AOO2

C3E-21359-A003

C3E-21359-A004

C3E-21359-A005

C3E-21359-A006

C3E-21359-A007

C3E-21359-A008

[3E-21359-0001

[3E-21359-0002

I3E-21359-0003

I3E-21359-0004

I3E-21359-0005

I3E-21359.0006

13E-21359-0007

13E-21359-0008

I3E-21359-0009

I3E-21359-0010

I3E-21359-0011

I3E-21359-0012

13E-21359-0013

\section{Revision}

0

0

0

0
0
0
0
0
0
0
0
0

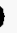

0

0

0

0

0

0

0

0

0

0

0

0

0

0

0

0

0

0

0
Titie

Pipe Support Details

Pipe Support Details

Pipe Supports in Tank Vault \& Valve Pit Descriptions \& Locations

Concrete- Plans

Structural

Concrete - Sections \& Details Sheet 1

Concrete - Sections \& Details Sheet 2

Concrete - Sections \& Details Sheet 3

Concrete - Sections \& Details Sheet 4

Steel-Liner Plate Embedments \& Details

Concrete - Sections \& Details Sheet 5

Steel - HVAC Duct Support Details

Steel - HVAC Equipment Support Details

Civil

Construction \& Operation Areas

Civil Details, Legend, \& References

Site Plan \& Sections

Yard Piping Plan

Yard Piping Plan, Profile \& Details

Drawing Index - Cover Sheet - Sheet 1

Drawing Index - Cover Sheet - Sheet 2

Instrumentation

Piping \& Instrument Diagram Steam Distribution System

Piping \& Instrument Diagram Caustic System

Piping \& Instrument Diagram Compressed Air Distr. System

Piping \& Instrument Diagram Low-Level Waste System

Piping \& Instrument Diagram Potabie/Process Water System

Piping \& Instrument Diagram HVAC System

Connection Diagram - Valves HV.9909, 9931 , ROV $9940,9941,9942$

Connection Diagram - Valves ROV-9922, 9927, 9929, 9930, 9932, 9933, 9943

Ascembly Panel K991, Side "A", "B", \& "C"

Panel K991, Cutout \& Drilling Details

Assembly Panel K991, Side "E", \& "F"

Ascembly Panel K992, Side "A", "B" \& "C"

Panel K992 Cutout \& Drilling Details 
WBS 13.1 - MONITORING AND CONTROL STATION FOR HRLAL - BUILDING 2099 continued

Drawing

Number

13E-21359-0014

I3E-21359-0015

[3E-21359-0016

[3E-21359-0017

13E-21359-0018

L3E-21359-0019

I3E-21359-0020

13E-21359-0021

L3E-21359-0022

I3E-21359-0023

LBE-21359-0024

L3E-21359-0025

[3E-21359-0026

I3E-21359-0027

LEE-21359-0028

I3E-21359-0029

I3E-21359-0030

13E-21359-0031

I3E-21359-0032

I3E-21359-0033

I3E-21359-0034

I3E-21359-0035

I3E-21359-0036

I3E-21359-0037

I3B-21359-0001

13B-21359-0002

13B-21359-0003

13B-21359-0004

13B-21359-0005

I3B-21359-0006

13B-21359-0007

13B-21359-0008

13B-21359-0009

I3B-21359-0010

13B-21359-0011

13B-21359-0012

13B-21359-0013

IBB-21359-0014

[3B-21359-0015

L3B-21359-0016

13B-21359-0017

I3B-21359-0018

13B-21359-0019

I3B-21359-0020
Revision

0

0

0

0

0

0

0

0

0

0

0

0

0

0

0

0

0

0

0

0

0

0

0

0

0

0

0

0

0

0

0

0

0

0

0

0

0

0

0

0

0

0

0

0
Tite

Panel K992, Graphic Display

Panel K992, Side " $D$ " \& "F"

Assembly Panel K993 Side "A", "B", \& "C"

Panel K993 Cutout \& Drilling Details

Assembly Panel K993, Side "E" \& "F"

Assembly Panel K994

Assembly Panel K995

Assembly Panel K996

Assembly Panel K997, K998, K999

Instrument Location

Instrument Installation

Instrument Installation

Instrument Installation

Instrument Air

Panel K991 Wiring Diagram Side " $D$ " \& "F"

Panel K991 Wiring Diagram Side " $E$ "

Panel K992 Wiring Diagram Side " $D$ " \& "F"

Panel K993 Wiring Diagram Side " $D$ " \& " $F$ "

Panel K993 Wiring Diagram Side "E"

Panel K994 Wiring Diagram

Panel K995 Wiring Diagram

Panel K996 Wiring Diagram

Instrument Installation

Installation Details Panel K9910

Process Instrument Tabulation

HVAC Instrument Tabulation

Loop Diagram MCS Tank Pressure PDT 9901

Loop Diagram MCS Tank Temp. TE-9902

Loop Diagram MCS Tank Temperature TE-9903

Loop Diagram MCS Tank Level LT.9904

Loop Diagram MCS Sump LVLS LE-9908, 9913, 9914

Loop Diagram MCS Tank Level LT-9906

Loop Diagram MCS Tank PH AE-9907

Loop Diagram Annulis Discharge PT-9910

Loop Diagram Caustic Addition Tank Temperature, TE-9911

Loop Diagram Caustic Addition Tank Level, LT-9912

Loop Diagram MCS Tank Vault Pressure PDT 9928

Loop Diagram Filter Plenum - 1 Total Pressure, Drop PDT-9952

Loop Diagram - Filter Plenum - 3 Total Pressure, Drop PDT-9954

Loop Diagram Fitter Plenum - 4 Total Pressure, Drop PDT-9955

Loop Diagram Filter Plenum - 5 Total Pressure, Drop PDT-9956

Loop Diagram Mist Eliminator PDT-9957

Loop Diagram Fitter Plenum - 8 Total Pressure Drop PDT-9961

Loop Diagram Fitter Pienum - 6 Total Pressure, Drop PDT-9962 
WBS 1.3.1 - MONITORING AND CONTROL STATION FOR HRLAL - BUILDING 2099 continued

Drawing

L3B-21359-0021

I3B-21359-0022

I3B-21359-0023

I3B-21359-0024

L3B-21359-0025

I3B-21359-0026

[3B-21359-0027

[3B-21359-0028

[3B-21359-0029

[3B-21359-0030

13B-21359-0031

13B-21359-0032

LB-21359-0033

13B-21359-0034

I3B-21259-0035

13B-21359-0036

I3B-21359-0037

13B-21359-0056

13B-21359-0057

I3B-21359-0058

H3E-21359-G001

H3E-21359-G002

H3E-21359-G003

H3E-21359-G004

H3E-21359-G005

H3E-21359-G006

H3E-21359-G007

I3B0213590038

I3B0213590039

I3B0213590040

I3B0213590041

I3B0213590042

I3B0213590043

I3B0213590044

I3B0213590045

IBBO213590046

13B0213590047

I3B0213590048

IBB0213590049

I3B0213590050

I3B0213590051

LBB0213590052

13B0213590053

\begin{tabular}{c} 
Revisio \\
\hline 0 \\
0 \\
0 \\
0 \\
0 \\
0 \\
0 \\
0 \\
0 \\
0
\end{tabular}

Tite

I \& C

Loop Diagram Filter Plenum - 7 Total Pressure Drop PDT.9964

Loop Diagram MCS Tank Vault Exit Air Flow, FE-9958

Loop Diagram Valve Pit Exit Air Flow FE-9959

Loop Diagram MCS Tank Vault Bypass Air Flow, FE-9960

Loop Diagram Mist Eliminator Air Flow FE-9966

Loop Diagram Exhaust Fan Inlet Press PDT-9970

Loop Diagram Combustible Gas AE-9965

Loop Diagram MCS Tank Level LE-9905

Loop Diagram Discharge Header Line Temperature, TE-9935

Loop Diagram Vault Sump to Tank Discharge Temperature, TE-9936

Loop Diagram Valve Sump Discharge Temperature, TE-9937

Loop Diagram Steam, Air \& Water Pressure PT-9917, 9919, \& 9933

Loop Diagram Caustic Tank Hi Level LE-9934

Loop Diagram Valve Box Leak Detector LE-9915, 9916

Loop Diagram Valve Box 1A

Loop Diagram Filter Plenum - 9 Total Pressure Drop PDT-9953

Loop Diagram Annulis Pressure PSL-9909

Loop Diagram Fan EF1 Status

Loop Diagram Fan EF2 Status

Loop Diagram Fiter Plenum - 10 Total Pressure Drop PDT-9979

ENVIRONMENTAL CONTROL (H,V\&AC)

Building Services Fluid System Diagram HVAC

Building Services HVAC Plan

Building Services HVAC Sections

Buildling Services HVAC Sections \& Details

Building Services HVAC \& Details

Building Services Control Diagram Heating, Ventilating \& Air Conditioning Sheet 1

Building Services Control Diagram Heating, Ventilating \& Air Conditioning Sheet 2

Loop Diagram Air Press. Alarm PSL-9929

Loop Diagram 2026 Service C HV-9909

Loop Diagram 2026 Service C HV-9931

Loop Diagram Jet Dis Valve Rov-9940

Loop Diagram Jet Dis Valve Rov-9941

Loop Diagram Jet Dis Valve Rov-9942

Loop Diagram Jet Valve ROV-9922

Loop Diagram Jet Vatve ROV-9923

Loop Diagram Jet Valve ROV-9924

Loop Diagram Jet Vatve ROV-9925

Loop Diagram Jet Valve ROV-9926

Loop Diagram PW Valve ROV-9929

Loop Diagram PW Vatve ROV-9930

Loop Diagram PW Vave ROV-9943

Loop Diagram Sparger Valve ROV-9927

Loop Diagram Unload Sump Val ROV-9932 


\begin{tabular}{|c|c|c|c|c|c|}
\hline REvision & DOCUMENT TITLE - IDEMTIFICATION/MUMBER & $\begin{array}{l}\text { DOC } \\
\text { TYPE }\end{array}$ & status & $\begin{array}{l}\text { CLIENT } \\
\text { ACTION }\end{array}$ & $\begin{array}{c}\text { ACrion } \\
\text { OUE }\end{array}$ \\
\hline & APPLICATIONS & & & & • \\
\hline \multirow[t]{2}{*}{0} & $\begin{array}{l}\text { C3E-20169-A012 } \\
\text { HIGH RADIATION LEVEL AMALYTICAL LABORATORY } \\
\text { INTERNAL PIPING } \\
\text { ORAHING INDEX - COVER SHEET }\end{array}$ & DUG & $\mathbf{F}$ & RC & $10-19-90$ \\
\hline & CIVIL & & & & \\
\hline 0 & $\begin{array}{l}\text { C3E-20169-A011 } \\
\text { HIGH RADIATION LEVEL ANALYTICAL LABORATORY } \\
\text { INTERNAL PIPING } \\
\text { CIVIL DETAILS ANO GEMERAL NOTES }\end{array}$ & Dur & $\mathbf{F}$ & RC & $10 \cdot 19 \cdot 90$ \\
\hline 0 & $\begin{array}{l}\text { C3E-20452-A002 } \\
\text { INTERHAL PIPING } \\
\text { LOCALITY MAP }\end{array}$ & OWG & $\mathbf{F}$ & $R C$ & $10-19.90$ \\
\hline \multirow[t]{2}{*}{0} & $\begin{array}{l}\text { C3E-20452-A004 } \\
\text { INTERNAL PIPING } \\
\text { CONSTRUCTION \& OPERATION AREAS }\end{array}$ & DWG & $\mathbf{F}$ & RC & $10-19-90$ \\
\hline & ELECTRICAL & & & & \\
\hline 0 & $\begin{array}{l}\text { E3E-20169-DOL1 } \\
\text { HIGH RADIATION LEVEL ANALYTICAL LABORATORY } \\
\text { ELECTRICAL - CONDUIT LAYOUT } \\
\text { PLAN - FIRST FLOOR }\end{array}$ & DWG & E & RC & $10-19-90$ \\
\hline 0 & $\begin{array}{l}\text { E3E- 20169-DOL2 } \\
\text { HIGH RADIATION LEVEL ANALYTICAL LABORATORY } \\
\text { ELECTRICAL - CONDUIT LAYOUT } \\
\text { PLAN AND SECTIONS - SECOND FLOOR }\end{array}$ & DWG & $\mathbf{F}$ & RC & $10 \cdot 19-90$ \\
\hline 0 & $\begin{array}{l}\text { E3E- } 20169-0052 \\
\text { HIGH RADIATION LEVEL ANALYTICAL LABORATORY } \\
\text { ELECTRICAL - CABLE LIST }\end{array}$ & DHG & $F$ & RC & 10.19 .90 \\
\hline 0 & $\begin{array}{l}\text { E3E- } 20169-0053 \\
\text { HIGH RADIATION LEVEL ANALYTICAL LABORATORY } \\
\text { ELECTRICAL. WIRING OIAGRAM }\end{array}$ & OWC & $\mathrm{F}$ & $\mathrm{RC}$ & $10 \cdot 19 \cdot 90$ \\
\hline \multirow[t]{2}{*}{0} & $\begin{array}{l}\text { E3E-21359-DOO1 } \\
\text { MONITORING \& CONTROL STATION FOR HRLAL } \\
\text { ELECTRICAL - ONE LIME DIAGRAM } \\
\text { DPI-5A 48OV MOTOR CONTROL CENTER }\end{array}$ & ovi & F & RC & $10 \cdot 19 \cdot 90$ \\
\hline & INSTRUMENTATIOM & & & & \\
\hline 0 & $\begin{array}{l}\text { 138-20169-0001 } \\
\text { HIGH RADIATIOH LEVEL AHALYTICAL LABORATORY } \\
\text { INSTRUMENT TABULATION }\end{array}$ & DHG & F & RE & $10-19 \cdot 90$ \\
\hline 0 & $\begin{array}{l}\text { 138-20169-0002 } \\
\text { HIGH RADIATION LEVEL AMALYTICAL LABORATORY } \\
\text { LOOP OIAGRAM } \\
\text { DRAIN LEAK DETECTION CELL NO. I PISL-260 }\end{array}$ & DWG & $E$ & $R C$ & $10-19 \cdot 90$ \\
\hline 0 & $\begin{array}{l}138 \cdot 20169-0003 \\
\text { HIGH RADIATION LEVEL AMALYTICAL LABORATORY } \\
\text { LOOP DIAGRAM }\end{array}$ & DUE & $F$ & $R C$ & $10-19 \cdot 90$ \\
\hline
\end{tabular}




\begin{tabular}{|c|c|c|c|c|c|}
\hline REVISION & DOCUMENT TITLE - IDENTIFICATION/NUMBER & $\begin{array}{l}\text { DOC. } \\
\text { TYPE. }\end{array}$ & status & $\begin{array}{l}\text { CLIENT } \\
\text { ACTION }\end{array}$ & $\begin{array}{l}\text { ACTION } \\
\text { DUE }\end{array}$ \\
\hline 0 & $\begin{array}{l}\text { 138-20169-0004 } \\
\text { HIGH RADIATION LEVEL ANALYTICAL LABORATORY } \\
\text { LOOP DIAGRAM } \\
\text { ORAIM LEAK DETECTION CELL NO. } 3 \text { PISL-2603 }\end{array}$ & DuG & $\mathbf{F}$ & RC & $10-19-90$ \\
\hline 0 & $\begin{array}{l}\text { 138-20169-0005 } \\
\text { HIGH RADIATION LEVEL ANALYTICAL LABORATORY } \\
\text { LOOP DIAGRAM } \\
\text { ORAIN LEAK DETECTION CELL NO. } 4 \text { PISL-2604 }\end{array}$ & DWG & F & RC & $10 \cdot 19 \cdot 90$ \\
\hline 0 & $\begin{array}{l}\text { 138-20169-0006 } \\
\text { HIGH RADIATION LEVEL AMALYTICAL LABORATORY } \\
\text { LOOP DIAGRAH } \\
\text { DRAIN LEAK DETECTION CELL NO. } 5 \text { PISL-2605 }\end{array}$ & DUt & $\mathbf{F}$ & RC & $10 \cdot 19-90$ \\
\hline 0 & $\begin{array}{l}\text { 138-20169-0007 } \\
\text { HIGH RADIATION LEVEL AHALYTICAL LABORATORY } \\
\text { LOOP DIAGRAM } \\
\text { DRAIN LEAK DETECTION CELL NO. } 6 \text { PISL-2606 }\end{array}$ & DUE & $\boldsymbol{F}$ & RC & $10-19-90$ \\
\hline 0 & $\begin{array}{l}\text { 138-20169-0008 } \\
\text { HIGH RADIATION LEVEL ANALYTICAL LABORATORY } \\
\text { LOOP DIAGRAM } \\
\text { ORAIN LEAK DETECTION UNLONOING CELL PISL- } 2607\end{array}$ & OWG & F & RC & $10 \cdot 19 \cdot 9 C$ \\
\hline 0 & $\begin{array}{l}\text { 138-20169-0009 } \\
\text { HIGH RADIATION LEVEL AHALYTICAL LABORATORY } \\
\text { LOOP DIAGRAM } \\
\text { ORAIN LEAK DETECTION UNLOADING CELL DOOR PISL-2608 }\end{array}$ & DWG & $\mathbf{F}$ & RC & $10-10 \cdot 9 \mathrm{C}$ \\
\hline 0 & $\begin{array}{l}\text { 13B-20169-0010 } \\
\text { HIGH RADIATION LEVEL ANALYTICAL LABORATORY } \\
\text { LOOP OIAGRAM } \\
\text { DRAIN LEAK DETECTION MAIN CELLS } 1,2,3,4 \text { PISL-26 }\end{array}$ & DWC & $E$ & $\mathrm{RC}$ & $10 \cdot 0 \%$ \\
\hline 0 & $\begin{array}{l}\text { 138-20169-0011 } \\
\text { HIGH RADIATION LEVEL ANALYTICAL LABORATORY } \\
\text { LOOP DIAGRAM } \\
\text { DRAIN LEAK DETECTION MAIN CELLS 5, } 6 \text { PISL-2610 }\end{array}$ & DUG & $\mathbf{E}$ & RE & $\because \cdot=$ \\
\hline 0 & $\begin{array}{l}\text { 138-20169-0012 } \\
\text { HIGH RADIATION LEVEL AKALYTICAL LABORATORY } \\
\text { LOOP DIAGRAM } \\
\text { DRAIN LEAK DETECTION MAIN DISCHARGE PISL-2611 }\end{array}$ & DWG & $\bar{F}$ & RC & $\because=0$ \\
\hline 0 & $\begin{array}{l}\text { 138-20169-0013 } \\
\text { HIGH RAOIATION LEVEL ANALYTICAL LABORATORY } \\
\text { LOOP DIAGRAM } \\
\text { SUMP LEVEL LE-2613, } 2614 \& 2615\end{array}$ & DUC & $F$ & $R C$ & $10 \cdot 10 \cdot 9 ?$ \\
\hline 0 & $\begin{array}{l}\text { 138-20169-0014 } \\
\text { HIGH RADIATION LEVEL ANALYTICAL LABORATORY } \\
\text { LOOP OIAGRAM } \\
\text { SUMP LEVEL LE-2616 AND } 2617\end{array}$ & DWG & $F$ & RE & $10 \cdot 19.90$ \\
\hline 0 & $\begin{array}{l}\text { 138-20169-0015 } \\
\text { HIGH RADIATION LEVEL ANALYTICAL LABORATORY } \\
\text { LOOP DIAGRAM } \\
\text { FLTR PIT SUMP A, 8, \& C LVL LE-2618, 2169, \& } 2620\end{array}$ & ows & $\mathbf{E}$ & RC & $10-19-90$ \\
\hline 0 & $\begin{array}{l}\text { 138-20169-0016 } \\
\text { HIGH RADIATION LEVEL ANALYTICAL LABORATORY }\end{array}$ & OWG & $F$ & $R C$ & $10-19 \cdot 90$ \\
\hline
\end{tabular}


DIM: 201-18000-1641

\begin{tabular}{|c|c|c|c|c|c|}
\hline REVISION & DOCLMENT TITLE - IDENTIFICATION/MUMBER & $\begin{array}{l}\text { DOC } \\
\text { TYPE }\end{array}$ & STATUS & $\begin{array}{l}\text { CLIENT } \\
\text { ACTION }\end{array}$ & $\begin{array}{c}\text { ACT:ON } \\
\text { OUE }\end{array}$ \\
\hline 0 & $\begin{array}{l}\text { I38-20169-0017 } \\
\text { HIGH RADIATION LEVEL ANALYTICAL LABORATORY } \\
\text { LOOP DIAGRAM } \\
\text { FLTR PIT SUMP G, H \& I LEVEL LE-2624, } 2625 \& 2626\end{array}$ & OWG & $\mathbf{F}$ & RC & $: 5-19-90$ \\
\hline $\mathbf{0}$ & $\begin{array}{l}\text { I38-20169-0018 } \\
\text { MIGH RADIATIOH LEVEL AKALYTICAL LABORATORY } \\
\text { LOOP OIAGRAM } \\
\text { FILTER PIT SUMP I LEVEL LE-2627 }\end{array}$ & Dus & $F$ & RE & $13-19.90$ \\
\hline 0 & $\begin{array}{l}\text { I3E-20169-0001 } \\
\text { HIGH RADIATION LEVEL AMALYTICAL LABORATORY } \\
\text { ASSEMBLY PANEL K261 }\end{array}$ & Dur & $\mathbf{F}$ & $\mathbf{R C}$ & $\because-19 \cdot 90$ \\
\hline 0 & $\begin{array}{l}\text { I3E-20169-0002 } \\
\text { MIGH RADIATION LEVEL AMALYTICAL LABORATORY } \\
\text { ASSEMBLY PAMEL K262 }\end{array}$ & DWG & $\mathbf{F}$ & RC & $\therefore=-19-90$ \\
\hline 0 & $\begin{array}{l}\text { I3E-20169-0003 } \\
\text { HIGH RADIATION LEVEL AHALYTICAL LABORATORY } \\
\text { ASSEMBLY PANEL K263 }\end{array}$ & DWG & $\mathbf{F}$ & RC & $\because-19 \cdot 90$ \\
\hline 0 & $\begin{array}{l}\text { I3E-20169-0006 } \\
\text { MIGH RADIIATION LEVEL ANALYTICAL LABORATORY } \\
\text { INSTRLHENT LOCATION }\end{array}$ & DWG & $\mathbf{F}$ & RC & $: 19-90$ \\
\hline 0 & $\begin{array}{l}\text { I3E-20169-0005 } \\
\text { HIGH RADIATION LEVEL AMALYTICAL LABORATORY } \\
\text { INSTRUMENT INSTALLATION }\end{array}$ & OWG & $\mathbf{F}$ & RC & $\because-19-90$ \\
\hline 0 & $\begin{array}{l}\text { I3E-20169-0006 } \\
\text { MIGH RADIAIION LEVEL ANALYTICAL LABORATORY } \\
\text { PANEL K26I } \\
\text { WIRING DIAGRAM }\end{array}$ & DWG & $F$ & $R C$ & $\because 99.90$ \\
\hline 0 & $\begin{array}{l}\text { 13E-20169-0007 } \\
\text { MIGH RADIATION LEVEL ANALYTICAL LABORATORY } \\
\text { PANEL K262 } \\
\text { UIRING DIAGRAM }\end{array}$ & DWG & $\mathbf{F}$ & RC & $\because:-19.93$ \\
\hline 0 & $\begin{array}{l}\text { I3E-20169-0008 } \\
\text { HIGH RADIATION LEVEL ANALYTICAL LABORATORY } \\
\text { PANEL K263 } \\
\text { HIRING DIAGRAM }\end{array}$ & DHC. & $F$ & Re & $\because=10.90$ \\
\hline & PIPING & & & & \\
\hline 0 & $\begin{array}{l}\text { P-20169-EC-002-X } \\
\text { (EXISTIMG UNION CARBIDE DRAUING) } \\
\text { ORAINAGE PLAN } \\
\text { "DEMOLITION" }\end{array}$ & DWG & $F$ & RC & $1:-19-90$ \\
\hline 0 & $\begin{array}{l}\text { P-20169-EC-003-X } \\
\text { (EXISTING UNION CARBIDE DRAHING } \\
\text { SERVICE PIPING PLAN } \\
\text { WDEMOLITION/RECONSTRUCTION" }\end{array}$ & DWE & $\mathbf{F}$ & $R C$ & $\because:-19-90$ \\
\hline 0 & $\begin{array}{l}\text { P-20169-EC-004-D-X } \\
\text { (EXISTING UNION CARBIDE DRAHING) } \\
\text { PIPING SECTIONS } \\
\text { DEEMOLITION/RECONSTRUCTION" }\end{array}$ & OWG & $F$ & $R C$ & $10-19-90$ \\
\hline
\end{tabular}




\begin{tabular}{|c|c|c|c|c|c|}
\hline REVISION & DOCUNENT TITLE - IDENTIFICATION/MUMBER & $\begin{array}{l}\text { DOC } \\
\text { TYPE }\end{array}$ & status & $\begin{array}{l}\text { CLIENT } \\
\text { ACTION }\end{array}$ & $\begin{array}{c}\text { ACTION } \\
\text { DUE }\end{array}$ \\
\hline 0 & $\begin{array}{l}\text { P-20169-EC-005-0-X } \\
\text { (EXISTINS UNION CARBIDE ORAHING) } \\
\text { PIPING SECTIONS \& OETAILS } \\
\text { "DEMOLITION/RECONSTRUCTION" }\end{array}$ & DUE & $F$ & $R C$ & $10-19-90$ \\
\hline 0 & $\begin{array}{l}\text { P-20169-EC-091-D-X } \\
\text { (EXISTING UNION CARBIDE DRAUING) } \\
\text { SERVICE \& DRAINAGE PIPING SECTIONS - SHEET } \\
\text { "DEMOLITIOW" }\end{array}$ & Oug & $\mathbf{F}$ & RC & $10 \cdot 19 \cdot 90$ \\
\hline 0 & $\begin{array}{l}\text { P-20169-EC-012-D-X } \\
\text { (EXISTING UNION CARBIDE DRAUING) } \\
\text { SERVICE \& DRAINAGE PIPING SECTIONS - SHEET } 2 \\
\text { "DEMOLITIOW" }\end{array}$ & Dus & $\mathbf{F}$ & $R C$ & $10-19-90$ \\
\hline 0 & $\begin{array}{l}\text { P-20169-EC-013-D-X } \\
\text { (EXISTING UHION CARBIDE DRAHING) } \\
\text { DRAINAGE PIPING PLAN, SECTIONS \& DETAILS } \\
\text { "DEMOLITIOH/RECONSTRUCTIOH" }\end{array}$ & Dwe & $F$ & RC & $10 \cdot 19 \cdot 90$ \\
\hline 0 & $\begin{array}{l}\text { P-20169-Y-047-E-X } \\
\text { (EXISTING VITRO DRAUING) } \\
\text { FLOW OIAGRAM - RCD \& PWO SYSTEMS } \\
\text { "DEMOLITION" }\end{array}$ & Dug & $F$ & RC & $10-19 \cdot 90$ \\
\hline 0 & $\begin{array}{l}\text { P-20169-Y-048-E-X } \\
\text { (EXISTING VITRO DRAWING) } \\
\text { PIPING - FLOW DIAGRAM FUME HOOO \& VACUUM EXHAUST S } \\
\text { "DEMOLITION/RECONSTRUCTION" }\end{array}$ & DWG & $\mathbf{F}$ & $R C$ & $10 \cdot 19 \cdot 90$ \\
\hline 0 & $\begin{array}{l}\text { P-20169-Y-051-E-X } \\
\text { (EXISTING VITRO ORAWING) } \\
\text { RCD PIPING DRAINS, IST FLOOR } \\
\text { PLANS \& OETAILS "OEMOLITION" }\end{array}$ & DUE & $\mathbf{F}$ & $R C$ & $10-19-90$ \\
\hline 0 & $\begin{array}{l}\text { P-20169-Y-059-E-X } \\
\text { (EXISTING VITRO ORAWING) } \\
\text { YARD PIPING PLAN \& OETAILS } \\
\text { "DEMOLITION" }\end{array}$ & DUG & $F$ & $R C$ & $10-19-90$ \\
\hline 0 & $\begin{array}{l}\text { P-20169-Y-060-E-X } \\
\text { (EXISTING VITRO DRAWING) } \\
\text { PIPING - FUME HOCO\& VACLUM EXHAUST SYSTEM } \\
\text { "DEMOLITION/RECONSTRUCTION" }\end{array}$ & OWG & $F$ & $R C$ & $10 \cdot 19 \cdot 90$ \\
\hline 0 & $\begin{array}{l}\text { P3E-20169-C021 } \\
\text { HIGH RADIATION LEVEL AMALYTICAL LABORATORY } \\
\text { PIPING - FLUID SYSTEM DIAGRAM } \\
\text { LOW LEVEL WASTE DRAINS }\end{array}$ & DWG & $F$ & $R C$ & $10-19-90$ \\
\hline 0 & $\begin{array}{l}\text { P3E-20169-CO22 } \\
\text { HIGH RADIATION LEVEL ANALYTICAL LABORATORY } \\
\text { PIPING - SYSTEM } \\
\text { LLH IST FLOOR PLAN }\end{array}$ & DUG & $\mathbf{F}$ & RC & $10-19-90$ \\
\hline 0 & $\begin{array}{l}\text { P3E-20169-C023 } \\
\text { HIGH RADIATION LEVEL AMALYTICAL LABORATORY } \\
\text { PIPING - SYSTEM } \\
\text { LLH ENLARGEO PLANS \& SECTIONS }\end{array}$ & DuE & $F$ & RC. & $10-19-90$ \\
\hline 0 & $\begin{array}{l}\text { PSE-20169-CO24 } \\
\text { HIGH RADIATION LEVEL AMALYTICAL LABORATORY } \\
\text { PIPING - SYSTEM } \\
\text { LLH DETALLS - SHEET }\end{array}$ & DWG & $\boldsymbol{F}$ & $R C$ & $10-19-90$ \\
\hline
\end{tabular}




\begin{tabular}{|c|c|c|c|c|c|}
\hline REvision & DOCANENT TITLE - IDEMTIFICATION/NLABER & $\begin{array}{l}\text { Doc } \\
\text { TrPE }\end{array}$ & status & $\begin{array}{l}\text { CLIENT } \\
\text { ACTION }\end{array}$ & $\begin{array}{c}\text { ACTIOW } \\
\text { DUE }\end{array}$ \\
\hline $\mathbf{0}$ & $\begin{array}{l}\text { P3E-20169-CO25 } \\
\text { MIGH RAOIATION LEVEL ANALYTICAL LABORATORY } \\
\text { PIPING - SYSTEM } \\
\text { LLH DETALLS - SHEET } 2\end{array}$ & DWt & $\mathbf{F}$ & RC & $10 \cdot 19-96$ \\
\hline 0 & $\begin{array}{l}\text { P3E-20169-CO26 } \\
\text { HIGH RADIATION LEVEL ANALYTICAL LABORATORY } \\
\text { PIPING - SYSTEM } \\
\text { ULH SECTIONS \& DETAILS }\end{array}$ & Dut & $\mathbf{F}$ & RC & $10-19 \cdot 90$ \\
\hline 0 & $\begin{array}{l}\text { P3E-20169-CO27 } \\
\text { HIGH RADIATION LEVEL AMALYTICAL LABORATORY } \\
\text { PIPING - SYSTEM. } \\
\text { FILTER PIT LLW. SECTIONS }\end{array}$ & Duts & $\mathbf{F}$ & RC & $10 \cdot 19 \cdot 90$ \\
\hline 0 & $\begin{array}{l}\text { P3E-20169-C028 } \\
\text { HIGH RAOIATION LEVEL AMALYTICAL LABORATORY } \\
\text { PIPING - SYSTEM } \\
\text { - SCRUBBER PITS LLW - PLANS }\end{array}$ & DWG & $\mathbf{F}$ & RC & $10 \cdot 19-90$ \\
\hline 0 & $\begin{array}{l}\text { P3E-20169-CO29 } \\
\text { HIGH RADIATION LEVEL AMALYTICAL LABORATORY } \\
\text { PIPING - SYSTEM } \\
\text { SCRUBBER PITS LLH - SECTIONS \& DETAILS }\end{array}$ & DWE & $\mathbf{F}$ & RC & $10-19-90$ \\
\hline $\mathbf{0}$ & $\begin{array}{l}\text { P3E-20169-C030 } \\
\text { HIGH RADIATION LEVEL ANALYTICAL LABORATORY } \\
\text { PIPING - SYSTEM } \\
\text { SCRUBBER PITS EXISTING DRAINS - RELORX }\end{array}$ & ONG & $F$ & $R C$ & $10-19-90$ \\
\hline 0 & $\begin{array}{l}\text { P3E-20169-CO31 } \\
\text { HIGK RADIATION LEVEL ANALYTICAL LABORATORY } \\
\text { PIPING - SYSTEM } \\
\text { CELLS } 16 \text { CONVEYOR DOOR LLH DRAINS }\end{array}$ & DUC & $F$ & RC & $10 \cdot 10 \cdot \%$ \\
\hline 0 & $\begin{array}{l}\text { P3E-20169-CO32 } \\
\text { HIGH RAOIATION LEVEL ANALYTICAL LABORATORY } \\
\text { PIPING - SYSTEM } \\
\text { LLW ANMULUS SENSING }\end{array}$ & DWG & $F$ & RC & $10 \cdot 10 \cdot \%$ \\
\hline 0 & $\begin{array}{l}\text { P3E-20169-CO35 } \\
\text { HIGH RADIATION LEVEL ANALYTICAL LABORATORY } \\
\text { PIPE SUPPORT DETAILS }\end{array}$ & DUG & $F$ & RC & $10 \cdot 10 \cdot 0$ \\
\hline 0 & $\begin{array}{l}\text { P3E-20169-CO36 } \\
\text { HIGH RADIATION LEVEL ANALYTICAL LABORATORY } \\
\text { PIPE SUPPORT DETAILS }\end{array}$ & OWri & $E$ & $R C$ & $10-19 \cdot 9$ \\
\hline 0 & $\begin{array}{l}\text { P3E-20169-CO37 } \\
\text { HIGH RAOIATION LEVEL ANALYTICAL LABORATORY } \\
\text { PIPE SUPPORTS ON LAB AND CELL DRAINS } \\
\text { DESCRIPTIONS AND LOCATIONS }\end{array}$ & DUE & $F$ & $R C$ & $10 \cdot 99.90$ \\
\hline 0 & $\begin{array}{l}\text { P3E-20169-CO38 } \\
\text { HIGH RADIATION LEVEL ANALYTICAL LABORATORY } \\
\text { PIPE SUPPORTS ON SCRUBBER PIT DRAINS } \\
\text { DESCRIPTIONS AND LOCATIONS }\end{array}$ & Dive & $F$ & RC & $10 \cdot 19 \cdot 90$ \\
\hline & STRUCTURAL & & & & \\
\hline 0 & $\begin{array}{l}\text { S3E-20169-8049 } \\
\text { HIGH RADIATION LEVEL ANALYTICAL LABORATORY } \\
\text { STRUCTURAL C CONCRETE } \\
\text { PLAN - EL. } 855 \div-0 "\end{array}$ & Dus & $\mathbf{F}$ & RC & $10-19-90$ \\
\hline
\end{tabular}




\begin{tabular}{|c|c|c|c|c|c|}
\hline REVISION & DOCNENT TITLE - IOENTIFICATION/NUMBER & $\begin{array}{l}\text { OOC } \\
\text { TYPE }\end{array}$ & STATUS & $\begin{array}{l}\text { CLIENT } \\
\text { ACTION }\end{array}$ & $\begin{array}{c}\text { ACPION } \\
\text { DUE }\end{array}$ \\
\hline 0 & $\begin{array}{l}\text { S3E-20169-8050 } \\
\text { HIGH RADIATION LEVEL ANALYTICAL LABORATORY } \\
\text { STRUCTURAL - CONCRETE } \\
\text { SECTIOUS \& DETALLS - SHEET I }\end{array}$ & Dut & $\mathbf{F}$ & RC & $10 \cdot 19 \cdot 90$ \\
\hline 0 & $\begin{array}{l}\text { S3E-20169-80S1 } \\
\text { MIGH RADIATION LEVEL AMALYTICAL LABORATORY } \\
\text { STRUCTURAL - CONCRETE } \\
\text { SECTIOWS \& DETAILS - SHEET } 2\end{array}$ & OWt & $\mathbf{F}$ & RC & $10-19-90$ \\
\hline 0 & $\begin{array}{l}\text { S3E-20169-8052 } \\
\text { HIEH RADIATION LEVEL AMALYTICAL LABORATORY } \\
\text { STRUCTURAL . CONCRETE } \\
\text { SECTIOHS \& DETAILS - SHEET } 3\end{array}$ & DUG & $\mathbf{F}$ & $R C$ & $10-19.80$ \\
\hline 0 & $\begin{array}{l}\text { S3E-20169-8053 } \\
\text { HIGH RADIATION LEVEL ANALYTICAL LABORATORY }\end{array}$ & DWG & $F$ & RC & $10.19 \cdot 90$ \\
\hline
\end{tabular}

STRUCTURAL - COMCRETE

SECTIONS AND DETAILS - SHEET 6 
DOE/OR/01-1311\&D2

ORNL/ER-270

\section{DISTRIBUTION}

1. A. D. Clay

2. R. A. Dean

3. J. T. Etheridge

4-5. T. H. Monk

6. E. C. Phillips

7. P. S. Wood

8. ORNL ER Document Management Center

9. Central ER Document Management Center

10. Laboratory Records Department

11. ORNL Patent Section

12. Central Research Library

13. Office of Assistant Manager for Energy Research and Development, DOE Oak Ridge Operations Office, P.O. Box 2001, Oak Ridge, TN 37831-8600

14-15. Office of Scientific and Technical Information, P.O. Box 62, Oak Ridge, TN 37831

16. R. O. Hultgren, DOE Oak Ridge Operations Office, P.O. Box 2001, Oak Ridge,TN 37831-8541

17. C. S. Mims, DOE Oak Ridge Operations Office, P.O. Box 2001, Oak Ridge, TN 37831-8541

18. L. L. Radcliffe, DOE Oak Ridge Operations Office, P.O. Box 2001, Oak Ridge, TN 37831-8541

19. L. C. M. Roddye, DOE Oak Ridge Operations Office, P.O. Box 2001, Oak Ridge, TN 37831-8541 